Dariusz Wybranowski

Uniwersytet Szczeciński

\title{
WARUNKI NATURALNE JAKO JEDEN Z CZYNNIKÓW TOWARZYSZACYCH PROWADZENIU DZIAŁAŃ WOJENNYCH W NARRACJI THIETMARA I GALLA ANONIMA. PRZYCZYNEK DO POLITYKI PIERWSZYCH PIASTÓW
}

\begin{abstract}
Streszczenie. Głównym materiałem badawczym dla autora tej publikacji są Kronika biskupa merseburskiego Thietmara i znacznie późniejsza, Kronika polska Galla Anonima. Jako zagadnienia będące przedmiotem analizy posłużyły takie kwestie, jak: przestrzeń i związane z nią problemy logistyczne oraz zaopatrzenia, działania wojenne prowadzone w terenie leśnym i w górach, ponadto rzeki i ich miejsce w działaniach wojennych. Pytaniami badawczymi dla autora są m.in. stopień obecności powyższych elementów środowiska naturalnego w obu kronikach, przy opisach kampanii i bitew, czy są one integralną częścią narracji, czy też stanowią jedynie dla kronikarzy informację pośrednią? W treści obecnego studium autor stara się udowodnić, że w przypadku Galla Anonima książę Bolesław Krzywousty zwyciężał nie tylko w starciach o charakterze militarnym, ale dzięki swej woli i cechom charakteru potrafił to także czynić w przypadku natury, np. pokonując masyw Sudetów podczas wojen z Czechami i Morawianami. Dla Thietmara okazją do umieszczenia informacji na temat roli natury $w$ działaniach wojennych były wojny toczone przeciwko Bolesławowi Chrobremu w latach 1002-1018. Dla kronikarza saskiego występującym niekiedy elementem opisu są działania wojenne w kontekście roli, jaką odgrywały duże rzeki. Jako przykłady mogą służyć działania w roku 1005, problemy z przeprawą przez rzekę Bóbr i bitwa stoczona koło Krosna, wyprawa księcia Mieszka II na Miśnię podjęta w 1017 r. i niespodziewany wylew Łaby, tragedia oddziału Luciców, którzy utonęli w nurcie Muldy, czy opis bitwy nad Bugiem stoczonej w 1018 r. Natomiast przykładem bitwy w terenie leśnym może być klęska armii Henryka II w kraju Dziadoszan na Śląsku, do której doszło w 1015 r. Analizując opisy Thietmara widać wyraźnie, że traktuje on rzeki jako żywioł bardzo groźny. Jednak warunki naturalne, w tym wspomniane rzeki, były dla niego jedynie uzupełnieniem, a nie głównym elementem narracji.
\end{abstract}


W Kronice polskiej Galla Anonima warunki naturalne, tj. puszcze i lasy, rzeki, jeziora i wysokie pasma gór są natomiast bardzo istotną częścią opisu działań wojennych władców piastowskich. Wyprawa na Kołobrzeg (1103) trwająca "5 dni” była dla kronikarza kolejnym przykładem jak książę Bolesław poradził sobie skutecznie z przestrzenią. Przypadki kampanii prowadzonych w zimie są opisywane podczas wojen z Pomorzanami i Prusami. Jednym z ciekawszych elementów zmagań z naturą u Galla jest wątek wyprawy Bolesława Śmiałego na Pomorze, podczas której utonęli w jednej z rzek jego rycerze noszący kolczugi. Przykładem "sądu Bożego" może być natomiast krwawa bitwa stoczona nad Bugiem między armią Bolesława Chrobrego a Rusinami, czy starcie nad jeziorem Gopło (1097). Podkreślić należy, że liczba egzemplifikacji związanych z warunkami naturalnymi u Galla Anonima jest bez porównania większa niż u Thietmara. Mają one nie tylko walor informacyjny, ale są też istotnym rozwinięciem kronikarskiej narracji. W przypadku wspomnianego autora stanowią dodatkowy walor literacki jego dzieła.

Słowa kluczowe: Thietmar z Merseburga, Gall Anonim, wojna w średniowieczu, rzeki podczas działań wojennych, działania wojenne w lesie i w górach, wojny w czasach pierwszych Piastów

\section{Wstęp}

Problem stosunku ludzi średniowiecza do przyrody, w tym pogody, fauny i flory, a także rezonansu klęsk żywiołowych, znalazł odbicie zwłaszcza w wydanym w 2000 r. zbiorze artykułów Cztowiek i przyroda w średniowieczu i we wczesnym okresie nowożytnym ${ }^{1}$. Owe studia nie podejmowały jednak analizy wpływu warunków naturalnych na szeroko rozumiane zagadnienia związane z wojną czy wpływem na przebieg wypraw wojennych, kampanii lub bitew toczonych $\mathrm{w}$ średniowieczu. Także opracowania o charakterze syntetycznym w starszej historiografii obcej (Hans Delbrück, Ferdinand Lot, Charles Oman czy Philippe Contamine) nie podejmowały tej kwestii jako odrębnego tematu, a jedynie jako niewielkie uzupełnienie do egzemplifikacji niektórych starć. Niektórzy autorzy polscy tak starszego pokolenia (m.in. Andrzej Nadolski, Andrzej Feliks Grabski), jak i piszący współcześnie, omawiając konflikty prowadzone do pierwszej połowy XII w. absolutnie nie pomijali roli warunków naturalnych (działań na terenach leśnych, w górach czy rzek i innych akwenów wodnych). Wśród analizowanych problemów znajdował się także czas trwania niektórych wypraw, związany z czynnikiem kluczowym wówczas - odległością.

${ }^{1}$ Cztowiek i przyroda $w$ średniowieczu $i$ we wczesnym okresie nowożytnym, red. W. IWAŃCZAK, J. Bracha, Warszawa 2000 (ibidem artykuly m.in. J. Strzelczyka, S. Byliny, J. Bartla, L. Kajzera, W. Iwańczaka, M. Jończyka, A. Samsonowicz, R. Kiersnowskiego, B. WojcieChowskiej, S. Lorenz, K. Brachy, W. Mrozowicza). 
Do tych zagadnień autor niniejszego studium także chciałby się odnieść. Jednak najważniejszymi pytaniami badawczymi są następujące kwestie:

- w jakim stopniu warunki naturalne (przestrzeń, lasy, góry, rzeki, jeziora, bagna) znalazły odbicie w niektórych źródłach narracyjnych, tj. kronikach biskupa Thietmara i Galla Anonima opisujących współczesne konflikty toczone w czasach pierwszych Piastów do połowy wieku XII?

- w jakim stopniu relacje Thietmara i Galla Anonima mogą być ważnym elementem do badania przebiegu ówczesnych kampanii i wojen, czy są one wiarygodne i czy wciąż mogą służyć do rekonstrukcji poszczególnych epizodów Polski za panowania pierwszych Piastów?

- czy dla wspomnianych wyżej kronikarzy wątki związane z warunkami naturalnymi stanowiły integralną część narracji, czy też były informacjami wycinkowymi lub jedynie towarzyszącymi, pozostającymi na marginesie prowadzonej zgodnie z ówczesną konwencją literacką opowieści?

- czy liczba relacji zawierających informacje u obu dziejopisów o wpływie niektórych elementów środowiska na działania wojenne może być porównywalna?

Głównym materiałem badawczym są dla autora: kronika biskupa merseburskiego Thietmara, zwłaszcza w kontekście wojen z lat 1002-1018 oraz Kronika Galla Anonima. Wspomniana kronika Thietmara, także jako „obca narracja”, jest praktycznie nie do zastąpienia, jeśli chodzi o szerszą wiedzę na temat stosunków państwa Piastów z Cesarstwem i przebieg wojen z lat 1002-1018, które mogą być jedynie cząstkowo uzupełnione przez roczniki i źródła późniejsze. Była ona także podstawą do kolejnych przekazów na temat panowania cesarza Henryka II, wojny lat 1015-1018 oraz stoczonej w 1018 r. (z udziałem kontyngentu saskiego) bitwie nad Bugiem pomiędzy siłami Bolesława Chrobrego a armią ruską księcia Jarosława Mądrego². W przypadku Galla Anonima autor dokonuje analizy tych epizodów z czasów wojen Bolesława II z Pomorcami, Bolesława Krzywoustego z Czechami, Cesarstwem oraz do 1113 r. prowadzonego podboju Pomorza, które zawierają odniesienia do warunków naturalnych. Na potrzeby obecnego studium autor zajął się informacjami związanymi z działaniami

2 A. Pleszczyński, Przekazy niemieckie o Polsce i jej mieszkańcach w okresie panowania Piastów, Lublin 2016, s. 111-114. 
w terenie podczas niektórych kampanii czy bitew prowadzonych za panowania Bolesława Chrobrego, Bolesława II Śmiałego, Władysława Hermana i Bolesława III Krzywoustego.

Jedną z głównych tez badawczych jest wykazanie przez autora dążenia kronikarza do podniesienia walorów literackich i erudycyjnych swego dzieła poprzez ukazanie wypraw wojennych (zwłaszcza jemu współczesnych) w szerszym kontekście. A zatem nie tylko suchych faktów, ale i pochwały ulubionego patrona - księcia Bolesława. Gall stara się go ukazać jako zwycięzcę w bitwach, ale i tego, który potrafi dobrze sobie radzić z przeciwnikiem znacznie gorszym od zwykłych wrogów - naturą. Żelazna wola księcia, talent dowódczy i skłonność do ryzyka pozwalały mu na pokonywanie słabo dostępnych dróg przez masyw Sudetów i lasy górskie, puszcze porastające dolinę Noteci, Pojezierze Pomorskie i duże odległości towarzyszące wyprawom wojennym. Dla Galla opis niektórych wydarzeń jest też okazją do wskazania, że niekiedy nadmierna brawura i chęć walki z przeciwnikiem może prowadzić do zguby, jak w przypadku wyprawy pomorskiej Bolesława II Śmiałego, którego rycerze utonęli w jednej z rzek.

\section{Problem odległości w wyprawach wojennych, kwestia organizacji marszu i transportu wojska oraz zaopatrzenia}

Aż do XIX-XX w. jedną z istotnych barier, która czasem stanowiła poważne ograniczenie dla dalekich wypraw wojennych, była przestrzeń. Jej szybkie pokonanie w spektakularny sposób, zwłaszcza w trudnych warunkach, było powodem do podziwu współczesnych, w tym kronikarzy, którzy swym piórem uwieczniali pamięć o podobnych rajdach w głąb kraju przeciwnika. O podobnych, spektakularnych wyprawach informuje kronika Galla Anonima. Pierwszą z podjętych wypraw Bolesława była przedsięwzięta na jesieni 1102 r. wyprawa na Białogard, który według opisu wspomnianego kronikarza był jednym z kluczowych ośrodków Pomorza. Kronikarz nazywa ów gród „królewskim miastem Alba”, co oddaje dobrze jego znaczenie ${ }^{3}$. Najważniejszym elementem była szybkość

3 Anonim tzw. Gall [dalej: Gall], Kronika polska, tłum. R. Grodecki, M. Plezia, Wrocław 1989, L. II, cap. 22. Wzorem dla tej nazwy miała być węgierska Alba Regia (Szekésfehérvar), zwana też Królewskim Białogrodem, zapewne znana dobrze kronikarzowi. O tej wyprawie w ostatnich latach S. Rosıк, Bolestaw Krzywousty, Wrocław 2013, s. 16; N. Delestowicz, Zbigniew. Ksiaże 
działań i przede wszystkim czynnik zaskoczenia, który pozwolił na dotarcie pod gród niespodziewanie i zapewne bardzo utrudnił skuteczną jego obronę. Wyprawa na Kołobrzeg, datowana na 1103 r., jak wynika z opisu Galla, doskonale pokazywała wybór kierunku ataku na jeden z kluczowych grodów i siedzibę księcia Świętobora ${ }^{4}$. Podobnie jak we wcześniejszym przypadku, znów bardzo ważnym jej elementem był czynnik zaskoczenia, przy jednoczesnym użyciu stosunkowo niewielkich liczebnie sił jazdy. Gall pisał, że w ciągu pięciu dni specjalnie wybrany oddział konnicy przebył drogę od Głogowa „dniem i nocą przez pustkowia” do grodu nad Parsętą̧. Możliwe, że początkowo Bolesław i ludzie z jego najbliższego otoczenia zakładali, że efekt końcowy kilku dobrze wybranych ataków na główne ośrodki Pomorza zapewni szybkie zwycięstwo i przyjęcie zwierzchnictwa piastowskiego. Niewykluczone, że na chęci szybkiego rozstrzygnięcia konfliktu zaważył też młody wiek księcia, widoczna wojowniczość i impulsywność charakteru, która szukała wciąż nowych wyzwań i dużego ryzyka.

Oddział piastowski skrycie przeprawił się przez Parsętę i podszedł pod wały grodu. Bolesław okazał się przezornym wodzem i zostawił na wypadek niespodziewanego ataku czy wypadu załogi kołobrzeskiej na swoje tyły dwa hufce odwodowe. Najprawdopodobniej znaczna część oddziału księcia podczas ataku walczyła pieszo, na podobieństwo tarczowników. Niewielkiej grupie udało się sforsować bramę grodową, ale z uwagi na przewagę liczebną Pomorców, zmuszona została do odwrotu. Z opisu Galla jasno wynika, że podczas walki większość wojów Krzywoustego zajęta była „zdobywaniem” i łupieniem bogatego podgrodzia, gdzie zapewne znajdowały się składy i kramy kupieckie. Natomiast odbiciem realnych działań, znanych być może potem przez Galla na podstawie relacji uczestników, była - po opanowaniu zaistniałego chaosu - zsynchronizowana akcja walk o poszczególne bramy grodu kołobrzeskiego. Mimo zaciętości

Polski, Kraków 2016, s. 168-169; D. Wy BRANOwski, Jeszcze raz o taktyce wojen pomorskich Bolestawa Krzywoustego oraz okolicznościach ich finatu, „Przegląd Zachodniopomorski” 2017, t. 32, z. 2, s. 72 i M. Kaproń, Koń w polskiej wojskowości, Warszawa 2018, s. 22.

${ }^{4} \mathrm{Na}$ ten temat, $c f$. m.in. K. MaleCZyŃsKi, Bolestaw III Krzywousty, Wrocław 1975, s. 131 i nast.; J. Spors, Pochodzenie dynastii ksiązęcych na Pomorzu Zachodnim w XI i XII w. - w szczególności Świętobora i Świętopetka z Kroniki Galla Anonima, „Roczniki Historyczne” 1983, t. 49, s. 8 i nast.; B. ŚLIWIŃski, Pomorze w polityce i strukturze państwa wczesnopiastowskiego (X-XII wiek), „Kwartalnik Historyczny" 2000, t. 107, z. 2, s. 29 i nast.; E. RYmaR, Rodowód ksiąząt pomorskich, Szczecin 2005, s. 87-89 i D. WybRANOWski, op. cit., s. 72.

5 Gall, L. II, cap. 28. 
walk, rycerstwu Bolesława nie udało się zdobyć samego grodu, musiał się zadowolić jedynie złupieniem i spaleniem zabudowań spustoszonego podgrodzia ${ }^{6}$. Jak w ogóle podobna wyprawa, trwająca „5 dni”, była możliwa w stosunkowo krótkim czasie? Dystans prowadzący od Głogowa nad morze i Kołobrzeg w prostej linii to ponad 300-330 km, należy też pamiętać, że trasa od dzielnicy Bolesława wiodła przez obszar rozlewisk Noteci i Warty i rozległe obszary lasów, gdzie droga może ulec znacznemu wydłużeniu.

Czy możliwa jest odpowiedź jaka w warunkach średniowiecznego środowiska naturalnego była potencjalna szybkość marszu armii czy jazdy?

Ponad 60 lat temu Andrzej Nadolski zajął się analizą wojen Chrobrego z Cesarstwem. Armia Henryka II w 1005 r. przebyła drogę „Licykawa-DobryługKrosno-Międzyrzecz" (tj. około 300 km w linii powietrznej) w ciągu $38 \mathrm{dni}$ (16 sierpnia - 22 września), z czego trzeba odliczyć 7 dni spędzonych nad Odrą7. Przeciętne tempo marszu tysięcy ludzi wynosiło zatem $10 \mathrm{~km}$ dziennie. Ten współczynnik, jak wskazał ów znany badacz wojskowości, został pow tórzony w kolejnych kampaniach w 1015 i 1017 r. ${ }^{8}$

Natomiast David Nicolle opisując wojnę Karola II Łysego w 841 r. wskazał: „Trudno ocenić jest szybkość i wytrzymałość ówczesnych armii frankijskich, lecz jasny jest fakt, że w trakcie przedłużających się kampanii szczególnie mocno cierpiały konie. Duży oddział konnych, który nie brał udziału w walce, był w stanie przebyć około $30 \mathrm{~km}$ lub nawet $40 \mathrm{~km}$ dziennie, podczas gdy zasięg niewielkich oddziałów mógł nawet urosnąć do $50 \mathrm{~km}$. Opis pościgu Karola II Łysego, autorstwa Nitharda, twierdzi, że w czasie 13-godzinnego marszu nocnego król przemierzył $60 \mathrm{~km}$. Następnego dnia jego ludzie przebyli kolejne $40 \mathrm{~km}$, co dawało godną podziwu odległość $100 \mathrm{~km}$ przebytą w ciągu 24 godzin. W trakcie marszu wykorzystano zapewne najlepsze konie, lecz nawet te zwierzęta były zmęczone i nie nadawały się do podjęcia natychmiastowej walki" ".

Z kolei, jak zaznaczył A.F. Grabski: „Szybkość posuwania się wojsk zależała od wielu czynników, przede wszystkim od składu wojsk (piesi czy konni), terenu w którym się poruszano (własny kraj czy nieprzyjacielski), bezdrożny, zalesiony,

${ }^{6}$ A.F. Grabski, Polska sztuka wojenna w okresie wczesnofeudalnym, Oświęcim 2015, s. 169 (tam również analiza działań wojennych tego starcia) i D. Wy вRANowski, op. cit., s. 72-73.

7 Thietmar, L. VI; A. NAdolski, Polskie sity zbrojne w czasach Bolestawa Chrobrego. Zarys strategii i taktyki, Oświęcim 2018, s. 99.

${ }^{8}$ A. NAdolski, op. cit., s. 99.

9 D. Nicolle, Jeździec Karolingów 768-987, Oświęcim 2018, s. 52-53. 
czy otwarty. Prawdopodobnie średnia szybkość marszu wojsk konnych wynosiła około $30 \mathrm{~km}$ dziennie (niekiedy znacznie więcej), natomiast wojsk pieszych, czy mieszanych znacznie mniej, około $20 \mathrm{~km}$. Długotrwałe marsze musiano co pewien czas przerywać postojami. Najczęściej po całodziennym wyczerpującym marszu, pod wieczór, w dogodnym miejscu rozkładano się obozem. $\mathrm{Na}$ miejsce odpoczynku wybierano okolicę łatwą do ewentualnej obrony: wykorzystywano polany leśne, tereny nad rzeką dostępne tylko po jej sforsowaniu. Tak było w kraju nieprzyjaciela. We własnym, nawet na pograniczu, rozbijano obóz zwykle pod grodem, jak Głogowem, Krosnem, Niemczą, o czym wiemy z wojen polsko-niemieckich. Gdy w kraju nieprzyjacielskim przygotowywano się do zdobycia grodu, obozowano w niedalekiej od niego odległości, ale tak, aby nikt o ich pobycie nie mógł się dowiedzieć (np. w lasach w pobliżu Kołobrzegu)"10.

Ostatnio o owym dystansie dzielącym Głogów od Kołobrzegu i sposobach jego pokonania pisał Jan Szymczak. Przyjął on odległość 330 km, a średni dystans, jaki dziennie musieli pokonać jeźdźcy Krzywoustego, to około $55 \mathrm{~km}^{11}$. Według niego podobny dystans był do pokonania w czasie pięciu dni (w szóstym przybyli oni pod gród) wspomnianych przez Galla, tym bardziej że J. Szymczak powołuje się na inne przykłady znane ze średniowiecza (i nie tylko) pokonywania przez konie znacznie dłuższego dystansu. Według tego autora średnia odległość pokonywana w XII-XIII w. dziennie konno to 25-45 km, a Władysław Jagiełło miał podczas objazdów państwa pokonywać dziennie od 20 do $50 \mathrm{~km}$. Zdaniem J. Szymczaka takie odległości jak organizowane obecnie dobowe konne wyścigi o dystansie $160 \mathrm{~km}$ czy dawniejsze przejazdy sięgające znacznie powyżej 100-110 km (np. wspomniane 180) stanowiły „wyczyny ekstremalne”12.

Bardzo istotnym czynnikiem była znajomość drogi i orientacja w terenie leśnym, co było nader ważne, tym bardziej że wyprawa w większości wiodła przez terytorium wroga. Kronikarz pisał, że ów konny oddział „kierował się według

10 A.F. Grabski, op. cit., s. 227-228.

11 Autor opisywał różne, znane źródłowo przypadki pokonywania długich dystansów konno. Np. w 1383 r. Sędziwój z Szubina miał przejechać z węgierskiego wówczas Zadaru do Krakowa w ciągu doby 60 mil (około $450 \mathrm{~km}$ - tak podaje J. SzYMCZAK!), a relacja nuncjusza papieskiego z 1565 r. mówiła, że polskie konie przebywają w ciągu czterech dni odległość z Krakowa do Wilna (120 mil). Innym przykładem było przejechanie drogi o długości $180 \mathrm{~km}$ przez Janusza, księcia mazowieckiego z Wizny do Wyszogrodu w ciągu dwu dni. Było to jednak możliwe dzięki rozstawnym koniom. Cf. J. SzymCZAK, Rycerz i jego konie, Bellerive-sur-Allier 2018, s. 90-91.

12 Ibidem, s. 90. 
gwiazd"13. Z kolei w relacji Herborda, autora żywotu św. Ottona, znalazła się informacja o nacinaniu kory drzew po drodze, tak by umożliwić sobie powrót ${ }^{14}$. A.F. Grabski w ślad za artykułem Kazimierza Ślaskiego o zasięgu lasów Pomorza, pisze że „na tej drodze nie było, zdaje się, wielkich i trudnych do przebycia lasów, ani też bagien, które utrudniałyby pochód”. To nie wydaje się jednak prawdopodobne, również trudno przypuszczać, by tak odległa wyprawa odbyła się bez jakiegokolwiek/jakichkolwiek przewodników. O jednym z takich ludzi, którzy towarzyszyli biskupowi Ottonowi, imieniem Paweł informuje wspomniany Herbord, określając go jako „centuriona” ${ }^{15}$. Jednak, jak pisał wcześniej Thietmar, trafiali się przewodnicy, którzy „zostali przekupieni i o swoje tylko dbali interesy, poprowadzili oni wojsko naokoło, przez pustynie i bagna, narażając je na różne uciążliwości. Opóźnili oni przy tym przez swoją podłą złośliwość marsz wojska, aby nie mogło ono szybko wystąpić przeciw nieprzyjacielowi"16. Ten zapis odnosił się do 1005 r. i wyprawy, która przemierzała obszar Łużyc, natomiast przewodnicy zostali pozyskani najprawdopodobniej przez ludzi Bolesława.

Jak wskazano wyżej, odległość i prawidłowe dotarcie do założonego celu było wyzwaniem, jakie stanęło przed oddziałem konnych Krzywoustego w 1103 r. Tak daleka i trudna pod względem warunków naturalnych droga musiała być dobrze rozpoznana, a jej przebieg musiał dawać efekt całkowitego zaskoczenia załogi i mieszkańców Kołobrzegu. Kwestia tak krótkiego czasu owej wyprawy nastręcza szereg wątpliwości. W ostatnich latach zakwestionował to Stanisław Rosik, który uważa, że teoretycznie byłoby to wprawdzie możliwe, lecz odniesione straty marszowe, zmęczenie ludzi i koni uniemożliwiłoby podjęcie skutecznej akcji militarnej ${ }^{17}$. Niezależnie jednak od czasu, jaki był potrzebny do pokonania drogi do Kołobrzegu, cel został osiągnięty przy pełnym zaskoczeniu przeciwnika.

Zatem, jak hipotetycznie mogła ona przebiegać? Znaczna część pogranicza wielkopolsko-lubusko-pomorskiego była obszarami słabo zaludnionymi i gęsto wtedy zalesionymi. A.F. Grabski starał się zrekonstruować trasę rajdu oddziału

${ }^{13}$ Gall, L. II, cap. 28; A.F. GRABSKI, op. cit., s. 168.

${ }^{14}$ Herbord Dialogus de Vita S. Ottonis episcopi Babenbergensis, [w:] Monumenta Poloniae Historica. Series Nova, t. 7, Warszawa 1974, L. II, cap. 5, 10; A.F. GrABSKI, op. cit., s. 227.

${ }^{15}$ Herbord..., L. II, cap. 9; D. WybRanowski, op. cit., s. 73.

${ }^{16}$ Kronika Thietmara [dalej: Thietmar], thum. M.Z. JedLICKI, Kraków 2002, L. VI, cap. 22 (16).

17 S. Rosik, op. cit., s. 166. 
Krzywoustego, która według niego wiodła (używając niekiedy nazw obecnych) „od Poznania na Ujście, Piłę, Barwice ku Parsęcie”18.

W okolicę samego wspomnianego grodu wiódł korytarz terytorialny położony między rzeką Regą a wspomnianą Parsętą, który trzeba było szybko przebyć, omijając jakiekolwiek ludzkie siedziby. Ludzie wchodzący w skład oddziału musieli również zabrać ze sobą odpowiedni zapas żywności na co najmniej kilka dni, bo zaopatrywanie się w nią we wrogim kraju byłoby bardzo trudne i groziło przedwczesnym odkryciem obecności owych jezdnych. Być może także i paszy dla koni, zwłaszcza podczas działań w zimie, choć ówczesne wierzchowce nie były tak delikatne i nie wymagały takiej dbałości i strawy, jak współczesne konie arabskie, angloaraby czy innych ras. Ewentualna konieczność pozyskiwania żywności na miejscu bądź postojów lub rozbijania obozów, niosła ze sobą wiele niebezpieczeństw ${ }^{19}$. Gdyby ktoś zauważył „obcych”, Pomorcy stosunkowo szybko mogliby zebrać siły i zaatakować z zaskoczenia. Zdawał sobie z tego sprawę i sam Krzywousty, przemawiając do swych rycerzy tuż przed podjęciem walki o Kołobrzeg („z tyłu nieprzyjaciel, a uciekać daleko”) ${ }^{20}$. O ile załoga Kołobrzegu została w porę ostrzeżona, miałaby również czas na przygotowanie obrony, lub nawet zasadzki, w którą najeźdźcy mogli zostać wciągnięci. Dostrzeżenie wrogich sił w środku obcego terytorium mogło się dla stosunkowo niewielkiego oddziału Bolesława Krzywoustego zakończyć bardzo źle, tym bardziej że miejsca i sposobności na przygotowanie leśnej pułapki na pewno by nie zabrakło. Teren leśny jest znakomitą okazją do zadania dużych strat przeciwnikowi, przy niewielkich nawet siłach własnych.

Działania towarzyszące wojnom pomorsko-piastowskim miały charakter typowo manewrowy, z głównym akcentem przeniesienia działań na teren przeciwnika i jego głębokie zaplecze. Pomorzanie rewanżowali się podobną strategią, gdy ich zagony pojawiły się na Mazowszu w roku $1109^{21}$ czy w nagłym ataku

18 A.F. GRABSKI, op. cit., s. 167.

19 D. Wybranowski, op. cit., s. 74.

20 Gall, L. II, cap. 28.

21 Gall, L. II, cap. 49; cf. K. Maleczyński, op. cit., s. 140; J. Hertel, Pomorze w myśli politycznej elity intelektualnej wczesnośredniowiecznej Polski (Gall Anonim i Wincenty Kadtubek), „Zapiski Historyczne” 1982, t. 47, z. 4, s. 70; J. BAnAszkiewicz, Potrójne zwycięstwo Mazowszan nad Pomorzanami - Gall, II-49 - czyli historyk między „rzeczywistością prawdziwą”, a schematem porzadkującym, [w:] Kultura średniowieczna i staropolska. Studia ofiarowane Aleksandrowi Gieysztorowi w 50-leciepracy naukowej, red. D. GAwINowa et al., Warszawa 1991, s. 305-312; D. WYBRANowski, op. cit., s. 77. 
na Spicymierz koło Uniejowa ${ }^{22}$ oraz podczas pobytu samego Bolesława w Rudzie $^{23}$. Podobny sposób walki miał na celu ominięcie głównych i mniejszych grodów, nie wdawanie się w jakiekolwiek ich zdobywanie i lupienie po drodze napotkanych wsi. Zasadniczym celem sił inwazyjnych było skryte pojawienie się tam, gdzie nikt się przeciwnika nie spodziewał. Dawało to także duże możliwości łupienia i brania w niewolę zaskoczonych mieszkańców wrogiego kraju w miejscu ataku czy koncentracji sił. Dlaczego już pierwsze wyprawy z lat 1102-1103, a potem w latach następnych bitwa pod Nakłem nad Notecią (1109) nie przyniosły rozstrzygnięcia o charakterze strategicznym i podboju Pomorza przez Krzywoustego? Na pewno przyczyniła się do tego niemożność skupienia się księcia tylko na wojnie z Pomorcami, ale także konieczność walki z najazdami Czechów na Śląsk i - zwłaszcza - mobilizacja praktycznie wszystkich sił do walki z najazdem Henryka Vw 1109 r. ${ }^{24}$

Poza tym od czasów Mieszka I trwałe opanowanie Pomorza utrudniała ogromna wola oporu i walki o przetrwanie jego mieszkańców ${ }^{25}$, przywiązanie do tradycyjnych wierzeń, ale także, jak niejednokrotnie zostało wspomniane, warunki terenowe. Faza wojen prowadzących do opanowania Pomorza przypominała w latach 1102-1109 i 1112-1116 nieco charakter działań armii frankijskiej Karola Wielkiego podczas wojen z Sasami w latach 772-804. Podobnie jak i Krzywousty, tak i Frankowie zmuszeni byli do walk na innych kierunkach, np. wojna z Longobardami w latach 773-774, wojny z tureckimi Awarami do 795 r., wyprawy przeciw hiszpańskim Maurom, walki z Celtami na pograniczu bretońskim i wyprawy na Luciców, w tym ta z 789 r. przeciw potężnemu księciu Drogowitowi.

Kolejnym czynnikiem łączącym te pozornie odległe od siebie cykle wojen był charakter teatru wojennego i istniejące tam warunki naturalne. Podobnie jak w znacznie późniejszym przypadku pomorskim, charakter działań zbrojnych

${ }^{22}$ Gall, L. II, cap. 43.

23 Gall, cap. 33.

${ }^{24}$ B. ŚLIWIŃSKI, op. cit., s. 67; D. Wybranowski, op. cit., s. 83.

${ }^{25}$ Zapis kronikarza - odnoszący się do wyprawy pomorskiej datowanej na 1107 r. - pod literacką metaforą brutalnie szczerze ukazywał rzeczywisty obraz tych wojen, bo przecież Pomorcy traktowali Krzywoustego i jego wojska jako okrutnych najeźdźców, palących i niszczących wszystko, cf. Gall, L. II, cap. 39: „I jak ogniem zionący smok, samym tylko tchnieniem paląc wszystko dokoła, a to, co nie spłonęło, rozbijając ruchem ogona, przebiega ziemię, by czynić spustoszenia - tak Bolesław uderzył na Pomorze, niszcząc żelazem opornych, a ogniem warownie”. 
był zdeterminowany przez ogromne obszary leśne, słabe zaludnienie wielu obszarów, brak dróg, rozlewiska rzek i rozległe bagna. To w znacznym stopniu niwelowało niewątpliwą przewagę potencjału zbrojnego Franków. Inny problem towarzyszący w nieodłączny sposób wyprawom wojennym i odległym celom marszów, to pojawiające się trudności w aprowizacji. Były one jednym z kluczowych problemów średniowiecznych armii, które wzrastały proporcjonalnie do ich liczebności, możliwości zaopatrzenia, także z uwagi na rosnący dystans od miejsca, skąd wyprawa wyruszyła czy gęstości zaludnienia, możliwości upraw i hodowli na danym obszarze. W razie przedłużania się wyprawy i pojawiających się problemów z zaopatrzeniem w żywność, wojsko zaczynało łupić także własne terytorium ${ }^{26}$. Opisując konflikty schyłku epoki Karolingów, D. Nicolle w jednej ze swych publikacji zaznaczył: „Plądrowanie nieprzyjacielskiego terytorium było kluczowym czynnikiem pozwalającym na wyżywienie armii”27.

Podczas krótkotrwałych wypraw, na własne potrzeby zabierano suszone lub wędzone mięso i kaszę, jako produkty, które się tak łatwo nie psuły, oraz mąkę, potrzebną do wypieku chleba. Natomiast podczas dłuższych ekspedycji armii towarzyszyły stada bydła rzeźnego, będące źródłem zaopatrzenia w świeże mięso $^{28}$. To jednak spowolniało jej marsz, a w razie zbyt szybkiego wykorzystywania podobnego rodzaju żywności, niekiedy zaś nawet zwykłego marnotrawstwa pozyskanego mięsa i podrobów, jej zapasy także po pewnym czasie zaczynały się kończyć. Zatem, na dłuższą metę, to nie rozwiązywało problemu. Konkludując, problemem była trudność długotrwałego przechowywania dużych ilości żywności, ale także jej sprawna dystrybucja i odpowiednie zaopatrzenie wojska, które zużywało bardzo dużo, ale nie było w stanie zapewnić (także z uwagi na problem z tzw. liniami zaopatrzenia) stałych dostaw tak dla ludzi, jak i paszy dla towarzyszących im zwierząt (koni, mułów, wołów).

Kolejnym czynnikiem, który nie ułatwiał szybkiego marszu na długie dystanse (zwłaszcza w razie wypraw wojennych na znaczną skalę i dużych oddziałów wojska - przyp. aut.), był tabor. Jak pisał wiele lat temu m.in. Andrzej Nadolski: „tabor złożony z wozów był wielkim obciążeniem, dawał w rezultacie zwiększenie długości kolumn marszowych, powstawanie zatorów w cieśninach i zwolnienie tempa pochodu. Wszystkie te czynniki, aktualne aż do dnia

\footnotetext{
26 P. RICHÉ, Życie codzienne w państwie Karola Wielkiego, Warszawa 1979; D. Nicolle, op. cit., s. 52.

${ }_{27}$ D. Nicolle, op. cit., s. 53.

28 A. NADOLSKI, op.cit., s. 43.
} 
dzisiejszego, występowały we wczesnym średniowieczu ze zdwojoną siłą wobec ówczesnego stanu dróg" ${ }^{29}$. Tabor był jednym ze środków przewozu pożywienia dla ludzi i paszy dla zwierząt, a szczególnie dla koni. Jak długo się dało, wojsko żywiło się tym, co stanowiło zapasy wiezione ze sobą. Gdy ich zabrakło, uciekano się może czasem do zakupu, a przede wszystkim do rekwizycji, szczególnie bezwzględnej w kraju nieprzyjacielskim. Jak słusznie zauważył cytowany już A. Nadolski: „O stałym dowozie środków zaopatrzenia z obszarów własnych oczywiście nie ma co mówić. Armia zdana była wyłącznie na to, co prowadziła ze sobą i co znalazła na drodze marszu. Ten stan rzeczy miewał doniosły wpływ na przebieg operacji wojennych"30.

Również, jak pisał m.in. Christopher Gravett, problem z zaopatrzeniem miał także związek z prostym faktem, że „próby inwazji [armii cesarskiej] na Polskę i Węgry często kończyły się głodem wśród atakujących, ponieważ miejscowi niszczyli lub przejmowali ich kolumny zaopatrzeniowe" ${ }^{11}$. Poza tym podczas marszu przez wrogie terytorium wojsko mogło je złupić i spustoszyć tylko raz, a liczba zagarniętego bydła, ptactwa domowego i upolowanych zwierząt wobec większej liczby żołnierzy była ograniczona i również nie mogła starczyć na długo.

Biskup Thietmar wspominał wcześniej w swej kronice o podobnych niebezpieczeństwach towarzyszących armii Henryka II podczas działań przeciw księciu Bolesławowi w 1005 r., odniosła ona wprawdzie wówczas zwycięstwo, lecz doznała strat w wyniku różnych zasadzek podczas marszu od rzeki Bóbr w kierunku na Poznań. Według jego relacji: „Wojsko jednak, które rozdzieliło się dla zebrania żywności i innych potrzebnych materiałów, poniosło wielkie straty od nieprzyjaciół, którzy zaatakowali je z zasadzki”32. Można przyjąć, że część z nich była efektem owego koniecznego rozdzielenia sił i doszło do niej w terenie leśnym. Trudno się dziwić, że w opisie zakończenia kampanii 1005 r., Thietmar wspomniał: „Z radością wracali tedy nasi do domu, ponieważ wielkie znosili trudy wskutek długich marszów i dotkliwego głodu, nieodłącznych od przykrości wojny"33. Gall Anonim jasno i w prostych słowach pisał, co ostatecznie

\section{Ibidem, s. 45.}

${ }^{30}$ Ibidem.

31 C. Gravett, Armie średniowiecznych Niemiec 1000-1300, Oświęcim 2019, s. 7.

32 Thietmar, L. V. Ostatnio na ten temat M. SAmp, Krosno Odrzańskie 1005 i 1015, ZabrzeTarnowskie Góry 2019, s. 50.

33 Thietmar, L. VI. 
zmusiło do odwrotu w 1110 r. armię Bolesława Krzywoustego, który pierwotnie zamierzał zająć Pragę - „I zaiste młodzieńczy plan wziąłby górę nad radami starszych, gdyby nie zabrakło chleba, który więcej może niż prawo rządzące ludzką społecznością"34.

\section{Walki w terenie leśnym i w górach}

Rozległe lasy i puszcze były nieodłączną częścią krajobrazu naturalnego ówczesnego świata. Nie inaczej było w przypadku ziem polskich, których większość pokrywały wówczas trudno dostępne niekiedy tereny leśne. W starszej historiografii wątek ten towarzyszył opisom i analizie warunków naturalnych państwa Piastów i terenów ościennych - m.in. u Stanisława Smolki, Kazimierza Ślaskiego i Kazimierza Wilińskiego ${ }^{35}$. Natomiast w ostatnich latach pojawił się u Pawła Babija przy okazji omawiania terenu Połabia ${ }^{36}$. Trudno dostępne kompleksy leśne bardzo sprzyjały obronie własnego obszaru plemiennego czy państwowego, często jednak sprzyjały ukryciu marszu własnych wojsk i nagłemu pojawieniu się na ziemiach będących obiektem ataku, czy to w celu ich złupienia, czy podboju.

Obecność sił inwazyjnych w głębi wrogiego terytorium, przy mało sprzyjających działaniom ofensywnym warunkach naturalnych mogła zakończyć się klęską, gdy własne oddziały były niszczone z ukrycia, np. podczas poszukiwania żywności, gdy zmuszone zostały do rozdzielenia się czy marszu w kilku kolumnach lub grupach. Szczególnie niebezpieczna stawała się droga przez tereny leśne (niekiedy w górach). Przykładem może być wielka klęska armii frankijskiej w 782 r. w górach Sűntel podczas kolejnej fazy zmagań z Sasami, którymi

34 Gall, L. III, cap. 22.

35 Obszernie (niekiedy w stylu literackim) o lasach i puszczach jako bardzo istotnej części krajobrazu naturalnego na ziemiach polskich, warunkach osadnictwa na terenie leśnym i niebezpieczeństwach towarzyszącym ówczesnym podróżom, cf. S. Smolka, Mieszko Stary i jego wiek, Warszawa 1959, s. 18-27. Natomiast próbę rekonstrukcji pierwotnego zasięgu lasów na pograniczu pomorsko-wielkopolskim, $c f$. K. ŚLASKI, Zasięg lasów Pomorza w ostatnim tysiącleciu, „Przegląd Zachodni” 1951, z. 5/6, s. 254-256 (ibidem mapa). Na temat lasów na terenie pogranicza mazowiecko-pruskiego, samych ziem Prusów w średniowieczu i wpływie warunków naturalnych na przebieg działań wojennych na tym obszarze w XII-XIII w., $c f$. K. Wiliński, Walki polsko-pruskie w X-XIII w. „Acta Universitatis Lodziensis", Folia Historica 15, 1984, s. 37-47.

36 P. BABIJ, Wojskowość Stowian Potabskich, t. 1, Wrocław 2017, s. 72-74. 
dowodził wówczas książę Widukind ${ }^{37}$. Podobny los spotkał również siły cesarza Henryka II w kraju Dziadoszan w roku 1015, podczas trzeciej z wojen za panowania Bolesława Chrobrego, o czym informuje w swej kronice Thietmar ${ }^{38}$. Do tego starcia doszło na jakimś „ciasnym pustkowiu, którego jedynym mieszkańcem był hodowca pszczół, później zresztą zabity [...] gdzie siły cesarskie na swoje nieszczęście rozbiły swój obóz”. Dalej kronikarz saski pisał, że: „Po pewnym czasie nieprzyjaciele ukryci w pobliskim lesie wznieśli potrójny okrzyk i zaraz potem rzucili się na nasze wojsko z łucznikami, którzy nadbiegli w zamieszaniu. Nasi dzielny stawiali opór przy pierwszym i drugim ataku i zabili wielu spośród nadbiegających. Lecz nieprzyjaciele, nabrawszy otuchy na widok ucieczki niektórych spośród naszych, zwarli się i uderzywszy powtórnie rozpędzili wszystkich i wybili pojedynczo przy pomocy zdradzieckich strzał. Arcybiskup Gero i palatyn Burchard ledwo uszli z życiem i donieśli o tym cesarzowi. Młodociany Ludolf dostał się z garstką do niewoli. Polegli i ze zbroi odarci zostali grafowie Gero i Folkmar oraz dwustu najprzedniejszych rycerzy, o których imionach i duszach niechaj Bóg wszechmogący w swym milosierdziu pamięta!"39

Andrzej Nadolski pisał bardzo trafnie: „Bitwa w kraju Dziadoszan w 1015 r. dała w rezultacie jedną z najcięższych klęsk jaką kiedykolwiek ponieśli agresorzy

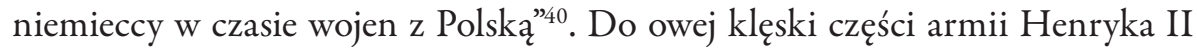
niewątpliwe przyczyniła się konieczność walki w lesie, a stosunkowo słaba zapewne widoczność i niewielki obszar bardzo utrudniał jakiekolwiek rozwinięcie jej sił. Leśny gąszcz znakomicie ułatwiał też rażenie strzałami z łuku Sasów, którzy przyjąwszy szyk obronny, byli w stanie zadać pewne straty atakującej piechocie Chrobrego. Z opisu Thietmara jasno wynika, że to polscy łucznicy strzelający z ukrycia rozstrzygnęli o klęsce oddziałów cesarskich i utracie tak dużej

37 EInhard, Vita Caroli, oprac. A. Gieysztor, Wrocław 1959; H. Delbrück, Średniowieczna sztuka wojenna, t. 1 Wczesne średniowiecze, Oświęcim 2018, s. 78-79; P. Riché, op. cit.; E.W. Wies, Karol Wielki. Cesarz i święty, Warszawa 1996; C. Oman, Sztuka wojenna w średniowieczu, Oświęcim 2013, t. 1, s. 76-77; G. Halsall, Wojna i spoteczeństwo w barbarzyńskiej Europie, Oświęcim 2015, s. 224 i ostatnio D. Nicolle, Podbój Saksonii lata 782-786, Oświęcim 2017, s. 46-78 oraz D. WyBRANOWSKi, op. cit., s. 74.

${ }^{38}$ Thietmar, L. VII, cap. 20.

39 Ibidem; S. Zakrzewski, Bolestaw Chrobry Wielki, Kraków 2000, s. 285-286; Zarys dziejów wojskowości polskiej do roku 1864, red. J. Sikorski, Warszawa 1965, t. 1, s. 59-60; J. STRZELCZYK, Bolestaw Chrobry, Poznań 1999, s. 149-150.

40 A. NAdolsKi, op.cit., s. 104-108 (tam też obszernie o rekonstrukcji przebiegu bitwy). Ostatnio na temat tego starcia M. SAMP, op. cit., s. 62-64. 
liczby rycerzy, którzy w terenie leśnym nie byli w stanie wykorzystać przewagi, jaką daje walka na koniu przeciw piechocie. Można dodać, że niektórzy autorzy „wzbogacali” (lub „wzbogacają”) relację biskupa merseburskiego o wątek „walki $\mathrm{w}$ terenie bagiennym" ${ }^{\prime 4}$.

Ze słów Thietmara nie wynika to wprost, ale być może owo „ciasne pustkowie” było rozległą polaną pośród gąszczu, lub wąską drogą leśną, a nie terenem, który był ograniczony przez jakieś rozlewiska lub bagna. Niewątpliwie dla setek ludzi, konnych i pieszych oraz towarzyszącej im kolumny wozów taborowych miejsce było fatalne do przyjęcia walki, bo podobna droga, ograniczona z obu stron drzewami, uniemożliwiała rozwinięcie szyków, skuteczny pościg, czy dobrą widoczność. Natomiast dla łuczników Chrobrego stłoczona na stosunkowo niewielkiej przestrzeni wroga armia była doskonałym celem, którą mogli razić skutecznie strzałami.

Opisując epizod towarzyszący jednej z wojen Bolesława II Śmiałego z Czechami (data nieznana, być może było to w latach 1076-1077), Gall wspominał o tym, że: „książę czeski z całą armią swoich rycerzy wkroczył do Polski (tj. najprawdopodobniej na Śląsk) i przebywszy leśne gąszcze rozłożył się [obozem] na pewnej równinie, dość odpowiedniej na miejsce walki. Usłyszawszy o tym, Bolesław Szczodry ochoczo pospieszył przeciw wrogom i pospiesznie obszedłszy ich, obsadził i zamknął drogę, którą przybyli”ł². Dalszy ciąg opowieści kronikarza w sposób pośredni mówi o tym, że las może być doskonałym schronieniem dla najeźdźców, którzy „jak wilki zgłodniałe porywają zdobycz”, umożliwia im skryte podejście do celu ataku, a po nim może być kryjówką, gdy wracają z łupami i inną zdobyczą̧ ${ }^{43}$. Można dodać, że dla Galla ta opowieść jest również okazją do wskazania tego, co czeka ludzi podstępnych i takich, którzy kłamstwem unikają rycerskiego starcia w uczciwej walce, gdy „decyduje męstwo”. Bolesław mając na uwadze fakt, że jego wojsko było strudzone długim marszem

${ }^{41}$ Jednym z pierwszych autorów był w tym względzie cytowany A. NADOLSKI, który pisał o marszu armii cesarskiej przez „podmokły las i niedostępny dla pancernej jazdy i taborów, które napotkały pasmo bagien”, IDEM, op. cit., s. 105. Za nim powtórzyli to inni autorzy, np. M. KAPROŃ, op. cit., s. 21; R. BARkowski, Budziszyn 1002-1018, Warszawa 2018, s. 196-200.

${ }^{42}$ Gall, L. I, cap. 24.

43 Ibidem: „Przedtem wychodząc z lasu jak wilki zgłodniałe, zwykliście byli, porwawszy zdobycz bezkarnie, w nieobecności pasterza znikać w kryjówkach leśnych, teraz jednak, gdy nadszedł myśliwy z oszczepami i psami rozpuszczonymi za śladem, będziecie mogli [już tylko] nie ucieczką lub podstępem, lecz męstwem ujść rozpiętych sieci”. 
(by zagrodzić drogę siłom wroga), wysłał ludzi, by powiadomili księcia czeskiego, że „następnego dnia stawi się do walki, i usilnie ich zapraszał, by i oni także pozostali na miejscu”ł" Jednak ów książę użył chytrego podstępu, by uniknąć okrążenia przez wojska Bolesława i ujść z zastawionej pułapki. Poprosił go: „nie godzi się, by tak wielki król trudził się do niższego do siebie, lecz jutro, jeśli jest synem Kazimierza, niech w pogotowiu oczekuje na swym stanowisku służb od Czechów”. Bolesław II miał w to uwierzyć i czekał do następnego dnia, by podjąć z nimi walkę. Okazało się jednak, że Czesi dużo wcześniej podjęli ucieczkę. Rozsierdzony tym faktem, poczuł się perfidnie oszukany, ruszył więc wraz ze swym wojskiem w pościg w kierunku Moraw. Udało mu się dopaść uchodzących Czechów i ,wielu z nich schwytał i zgładził, po czym zawrócił, zły na siebie, że tak mu uciekli” ${ }^{\prime 35}$.

Ta krótka opowieść to nie tylko budujący przykład, że tych którzy stosują kłamstwa i podstęp czeka nieuchronna kara. W tym wypadku miejscem, które było zawiązaniem historii, było wyjście sił czeskich z lasu, który umożliwił im nieoczekiwane pojawienie się gdzieś na pograniczu polsko-morawskim i równina, która miała stać się miejscem „rycerskiego starcia” obu armii, lecz wiarołomstwo Czechów spowodowało, że ich los dopełnił się gdzie indziej.

W zakończeniu opisu nieudanej wyprawy Henryka V przeciw Polsce (1109) u Galla wyraźnie widać, że Krzywousty narzucił swym przeciwnikom konieczność radzenia sobie z „taktyką wojny szarpanej”, która wymagała stałej czujności i kosztowała brak odpoczynku ${ }^{46}$. Istotną rolę w niej odgrywały zasadzki urządzane w terenie leśnym. Gall wskazał, że niemieccy najeźdźcy zaczęli bać się oddalać choćby na niewielką odległość od własnego obozu, „żaden giermek nie poważył się trawy zbierać, nikt nie wychodził nawet za swoją potrzebą poza wyznaczoną linię straży. Obawiano się Bolesława w dzień i w nocy, ciągle mając go w pamięci. [...] Gdy ukazał się jakiś gaik lub zarośla, wołano »strzeż się tam się kryje! «"

44 Ibidem.

45 Ibidem.

46 Gall, L. III, cap. 10: „Nie było miejsca, gdzie nie domyślano by się Bolesława. W ten sposób nękał ich bez wytchnienia, porywając po kilku jak wilk, raz z przodu, raz z tyłu, innym razem zaś z boku nastając. Dlatego też rycerstwo cały dzień szło w pełnym rynsztunku, spodziewając się nieustannie zjawienia się Bolesława. W nocy także wszyscy spali w kolczugach, lub tez stali na stanowiskach, inni odbywali straże, albo przez cała noc obchodzili obóz dookoła, albo wołali »Czuwajcie, strzeżcie się, pilnujcie! «".

47 Ibidem. 
W obu kronikach, choć w bardzo różnym stopniu, znalazły się nawiązania do walk w terenie górskim czy wykorzystania w celach militarnych wzniesień terenu. Przy opisie oblężenia Miśni w kronice Thietmara znalazł się bardzo ciekawy fragment ukazujący sposób dowodzenia przez Mieszka II, który „przypatrywał się wszystkiemu z wznoszącej się obok góry, oczekiwał na przybycie reszty rycerzy", którzy w tym czasie wyruszyli na pustoszenie wrogiego kraju ${ }^{48}$.

Okazją do ukazania waleczności tak Bolesława, jak i jego hufców w bardzo trudnym do walki obszarze Sudetów były dla Galla te epizody, które dotyczyły wypraw na Morawy w 1103 r. podjętych przeciwko księciu Świętopełkowi. Jedna z nich mogła przynieść siłom polskim klęskę, ponieważ „były one objuczone łupami”, co w domyśle wydatnie zmniejszało ich mobilność i tempo marszu. Wykorzystując górski teren, porośnięty lasem, i jego znajomość, Morawianie „wyprzedziwszy okrężną ścieżką Polaków” uderzyli na nich z zaskoczenia ${ }^{49}$. Tylko dzięki determinacji i waleczności jednego z hufców Bolesława można było zatrzymać atak sił Świętopełka i uniknąć zniszczenia. Gall nie omieszkał przy tym ukazać zaciętości i obrazu krwawego boju: „Wtedy to szczęk [mieczy] uderzających o hełmy rozbrzmiewał w wąwozach górskich i gąszczach leśnych, iskry ognia krzesane z żelaza błyskały w powietrzu, trzaskały włócznie, łamiąc się o tarcze, rozcinano piersi, a ręce i głowy, i porąbane ciała drgały [tu i tam] po polu. Oto Pole Marsowe, oto igrzysko Fortuny! Na koniec tak się znużyły obie strony i zrównały straty w zabitych rycerzach, że ani Morawianie nie osiągnęli wesołego zwycięstwa, ani Polacy nie ściągnęli na siebie znamienia hańby" 50 . Można dodać, że podczas tego starcia jeden z najbardziej zaufanych ludzi Bolesława - komes Żelisław stracił rękę, jednak jak wskazał dziejopis, książę „dla uczczenia go zwrócił mu złotą rękę, zamiast cielesnej" ${ }^{\prime 1}$.

Następna wyprawa Krzywoustego na Morawy, podjęta prawdopodobnie w tym samym 1103 r., była dla Galla okazją do wygłoszenia krótkiej pochwały na cześć księcia, który wprawdzie nie odniósł jakiegoś spektakularnego sukcesu politycznego, bo efektem było „więcej pożogi” (przy braku oporu stawianego przez Morawian). Natomiast Bolesław „pozyskał niemałą sławę z uwagi na trudność przedsięwzięcia. Albowiem od strony Polski Morawy tak są odgrodzone

\footnotetext{
48 Thietmar, L. VII; A.F. Grabski, Polska sztuka..., s. 144.

49 Gall, L. II, cap. 25.

${ }^{50}$ Ibidem.

${ }^{51}$ Ibidem.
} 
stromymi górami i gęstymi lasami, że nawet dla spokojnych podróżników, idących pieszo i bez pakunków, drogi są tam niebezpieczne i nader uciążliwe" 52 .

Opisując kampanię 1110 r. i wyprawę na północne Czechy, po raz kolejny kronikarz pisał o problemach, jakich nastręczał marsz sił polskich w terenie leśnym i w górach. Nie omieszkał porównać jej do przejścia Hannibala przez Alpy, wykazując oczywiście znacznie większą skalę trudności towarzyszących armii Bolesława, niż tych, z którymi miał do czynienia sławny wódz kartagiński i jego wojska ${ }^{53}$. Właśnie ten opis jest doskonałym dowodem, że ulubiony przez kronikarza władca ma nie tylko talent militarny i niejednokrotnie potrafił zwyciężać pogańskich Pomorzan i Prusów, poza tym Czechów i Niemców. Żelaznej woli Bolesława i prowadzonym przez niego wojskom musi ulec także natura, w tym wypadku wysokie góry, porośnięte gęstymi lasami. Pogranicze śląsko-czeskie i śląsko-morawskie stanowiło zatem granicę naturalną z „miejscami gdzie nie stanęła ludzka stopa”, co w widoczny sposób było dla kronikarza powodem do wielu obaw ${ }^{54}$.

Jak się okazało, liczne oddziały wojska nie były w stanie, przy braku znajomości terenu i zupełnym braku dróg, zachować ustalonego porządku marszu. Droga przez górskie lasy nie pozwalała również na jakiekolwiek rozwinięcie szyku, ale przede wszystkim na sprawną łączność między poszczególnymi oddziałami. Dowodem na to był opisany przez kronikarza epizod, gdy część sił idąca wraz z Bolesławem przez las, nagle zobaczyła inny oddział, który początkowo został wzięty za Czechów. W porę jednak, „po znakach polskich” zorientowano się, że to „swoi”, co w ostatniej chwili pozwoliło na uniknięcie bratobójczej walki ${ }^{55}$.

Wojowie Krzywoustego, jak pisał kronikarz, dowiedzieli się także o zasiekach leśnych, jakie Czesi sporządzali, oraz „czyhających zasadzkach”56. Dla Galla, jak już wcześniej zostało wspomniane, lasy porastające Sudety i górskie kotliny to teren bardzo niebezpieczny i miejsce, gdzie siły czeskie spodziewały się okrążyć i zniszczyć polskie oddziały. Tylko walka wręcz dawała jakiekolwiek szanse na zadanie strat przeciwnikom, o czym mówi jedna z relacji ze starć leś-

52 Ibidem, L. III, cap. 26.

53 Ibidem, L. III, cap. 21. Na temat tego fragmentu opisu Galla i ówczesnych warunków życia ludzi na obszarze lasów górskich, S. SMOLKA, op. cit., s. 21-22.

${ }^{54}$ Gall, L. III, cap. 21.

55 Ibidem, L. III, cap. 23.

${ }^{56}$ Ibidem. 
nych z Czechami ${ }^{57}$. Z opisu kronikarza można wnioskować, że do starcia Polaków z Czechami doszło dosyć niespodziewanie, gdy ci ostatni byli tak pewni zwycięstwa, że zaniechali dotychczasowej ostrożnej taktyki działań, zmierzającej do stopniowego wyczerpania przeciwnika. Owa leśna bitwa, która przerodziła się w klasyczny „bój spotkaniowy” prowadzona była w warunkach braku możliwości współdziałania sił polskich. Jako pierwszy w starcie z Czechami i współdziałającymi z nimi Niemcami wszedł hufiec przyboczny Bolesława, złożony z młodych rycerzy, który zadał według kronikarza znaczne straty przeciwnikowi. Inną bitwę w tym samym czasie, niezależnie od polskiego księcia, stoczył także oddział dowodzony przez wojewodę Skarbimira. Gall wspomniał też o udziale w bitwie czeskiego księcia. Po bitwie Bolesław, obawiając się podstępu lub przygotowanej zasadzki w jakiejś nie wymienionej z nazwy kotlinie, zabronił swoim wojom pościgu za rozbitym przeciwnikiem ${ }^{58}$.

Odpowiednie przygotowanie pola bitwy w terenie leśnym, dla ludzi znających go bardzo dobrze, pozwalało na skuteczne ukrycie się i atak z zaskoczenia, wyniszczenie wrogiego oddziału na dystans, choćby przez ostrzał z łuków i użycie oszczepów, także zamknięcie dróg ewentualnego odwrotu przez prowizoryczne zapory i zasieki, niekiedy bardzo trudne do sforsowania. Dobrym momentem był także nagły atak podczas przeprawy przez rzekę. O tym, jak własna przewaga ulega istotnemu zniwelowaniu podczas szeregu starć w gęstym lesie, także przez brak możliwości rozwinięcia sił, przekonały się trzy legiony Kwintyliusza Warrusa (XVII, XVIII i XIX) w 9 r. ne. w Germanii podczas starcia w Lesie Teutoburskim ${ }^{59}$.

Wyprawy na Białogard i Kołobrzeg z lat 1102/1103 były zatem z uwagi na szczupłość własnych sił przedsięwzięciem bardzo śmiałym i ryzykownym. Jednak przy odpowiednim wyzyskaniu czynnika zaskoczenia miały spore szanse na powodzenie. Podobna ekspedycja wspomnianego poniżej biskupa halberstadzkiego Burcharda wydarzyła się kilkadziesiąt lat wcześniej w przypadku wojen Sasów z Redarami. Nie należy wykluczyć, że pamięć i wiedza o niej oraz podobnych wyprawach była znana piastowskim wodzom.

${ }^{57}$ Ibidem, L. III, cap. 22.

${ }^{58}$ Ibidem. Powyższa bitwa, znana zwłaszcza z opisu Kosmasa, została stoczona w październiku 1110 r. nad rzeką Trutiną, dopływem Cidliny. Ostatnio na ten temat S. Rosık, op. cit., s. 126-127 (tam też inna literatura).

59 P. Rochala, Las Teutoburski 9 n.e., Warszawa 2005; C.S. MaCkAY, Starożytny Rzym. Historia wojskowa i polityczna, Warszawa 2014, s. 257. 
Karl Schünemann opisując na podstawie przekazów Helmolda z Bozowa walki Sasów ze Słowianami wskazywał na fakt następujący - im wyprawa zbrojna była mniejsza, tym bardziej przez swą wysoką mobilność i efekt zaskoczenia mogła liczyć na sukces (jako przykład mogą służyć także wyprawy Henryka Gotszalkowica obodrzyckiego przeciw Brzeżanom i Ranom) ${ }^{60}$. Mała liczebność była podyktowana również trudnościami w zaopatrzeniu i w wyżywieniu przez dłuższy czas. Ponadto stosunkowo niewielka, lecz dobrze uzbrojona i wyćwiczona w walce grupa wojowników mogła stać się istotnym czynnikiem rozstrzygającym.

\section{Wpływ pór roku na prowadzenie działań wojennych}

Warunki pogodowe i pory roku były dla działań wojennych prowadzonych w czasach średniowiecza kwestią kluczową. Najbardziej optymalną porą była późna wiosna i okres lata. Dla armii frankijskiej w czasach Merowingów, jak i Karolingów bardzo istotną sprawą było zapewnienie paszy dla koni, ponieważ ciężkozbrojna jazda stanowiła podstawę sił zbrojnych. Coroczny przegląd wojska urządzano w tradycji rzymskiej w marcu jako Campus Martius, jednak potem zastąpiony on został przez Campus Maius. Jak wskazał m.in. D. Nicolle: „W rzeczywistości armie Franków zbierały się w różnych terminach, zwykle między marcem a majem, a lokalizacja popisu była uzależniona od kierunku planowanej wyprawy wojennej. Pozostałymi czynnikami warunkującymi czas popisu były dostępność paszy dla koni oraz otwarcie przełęczy górskich po odwilży i stopnieniu śniegów [...] Różne kapitularze wskazują na to, że wasale potrzebowali trzech miesięcy na zebranie zapasów żywności i sześciu na przygotowanie broni i odzienia" ${ }^{1}$.

Na optymalny wybór pory działań wojennych wskazał wcześniej A. Nadolski: „Ograniczony w założeniu czas trwania wysiłku wojennego zmuszał do maksymalnego wykorzystania najdogodniejszej pory roku. Było nią z reguły lato i to raczej późne lato oraz początek jesieni. W tych miesiącach (sierpieńwrzesień) zbiory były już ukończone, można więc było zabezpieczyć sobie zapasy

${ }^{60}$ K. Schünemann, Deutsche Kriegsführung im Osten während Mittelalters, „Deutsches Archiv für Geschichte des Mittelalters" 1938, Jg. 2, s. 77.

${ }^{61}$ D. Nicolle, Jeździec..., s. 49. 
prowiantu i paszy we własnym kraju, a ponadto, co odgrywało rolę szczególnie ważną, można było wyżywić wojsko z rekwizycji na terenie działań wojennych"62.

Natomiast działania wojenne prowadzone podczas zimy i wczesnej wiosny, mimo występujących wspomnianych wyżej problemów, wcale nie były w średniowieczu ewenementem. Zaznaczyć należy, że podobne trudności, także związane z warunkami naturalnymi, książę Bolesław napotkał podczas prowadzonych równolegle do zmagań z Pomorzanami wypraw na Prusów (1108, 1110/1111, 1115), które nie przyniosły istotnego rozstrzygnięcia politycznego, czy zdobyczy terytorialnych, a jedynie łupy i spustoszenie atakowanych obszarów $^{63}$. Jak wskazał Kazimierz Wiliński: „Wiosną 1108 r. polskie oddziały wdarły się na obszary zamieszkane przez plemię Sasinów, niestety, z powodu niewłaściwie wybranej pory ataku nie osiągnięto żadnych istotnych sukcesów poza zwyczajowym zagarnięciem prawdopodobnie dużej ilości jeńców i innych dóbr materialnych, które Krzywousty rozdzielał między rycerstwo i drużynników, by pozyskać ich dla siebie"64.

W przypadku drugiej wyprawy na Białogard i Kołobrzeg (prawdopodobnie w 1105/1106 r. lub nawet 1106/1107), oddział dowodzony przez samego Bolesława wykorzystał okres pory zimowej i skute przez lód przeszkody wodne. Kronikarz pisał, że „Znowu zimą zebrali się Polacy, by wkroczyć na Pomorze, bo łatwiej zdobywać warownie, gdy bagna zamarzną"65. Tym razem jednakże czynnik zaskoczenia nie przyniósł korzystnego rozstrzygnięcia. Bolesław nie zdobył grodu niemal z marszu, jak to stało się kilka lat wstecz, bo najprawdopodobniej został on dodatkowo umocniony, poza tym Pomorcy już wiedzieli, że prędzej, czy później niebezpieczeństwo polskiego ataku może realnie zaistnieć i stanowi to raczej tylko kwestię czasu. Książę zmuszony został do budowy obozu i podjęcia działań o charakterze klasycznej wojny pozycyjnej ${ }^{66}$. Gall po raz kolejny wspomina o użyciu przez oddziały piastowskie machin oblężniczych ${ }^{67}$.

\footnotetext{
${ }^{62}$ A. NADOLSKI, op. cit., s. 67.

${ }^{63}$ Gall, L. II, cap. L. II, cap. 42, L. III, cap. 24; J. PowIERSKI, Stosunki polsko-pruskie do 1230 r. ze szczególnym uwzględnieniem roli Pomorza Gdańskiego, Toruń 1968, s. 101-102; K. MaleCzyŃsKi, op.cit., s. 140-141; K. WILIŃsKI, op. cit., s. 136-130; B. ŚLIWIŃsKI, op. cit., s. 32.

${ }^{64}$ K. WilińsKI, op. cit., s. 136.

${ }^{65}$ Gall, L. II, cap. 39.

${ }^{66}$ Ibidem.

${ }^{67}$ Ibidem.
} 
Okres zimy towarzyszył też jego wyprawie pruskiej, datowanej na przełom 1110-1111 r. Jak pisał Gall: „Bolesław [...] wkroczył do Prus, krainy północnej, lodem ściętej, podczas gdy nawet władcy Rzymu, walcząc z barbarzyńskimi ludami zimowali w przygotowanych [na to] warowniach, a nie wojowali przez całą zimę. Wkraczając do Prus, z lodu na jeziorach i bagnach korzystał jakoby z mostu, bo nie ma do owego kraju innego dostępu, jak tylko przez jeziora i bagna. A przeszedłszy jeziora i bagna i dotarłszy do kraju zamieszkanego, nie zatrzymał się na jednym miejscu, nie oblegał grodów, ani miast, bo ich tam nie ma, gdyż kraj ten jest broniony przyrodzonymi warunkami i naturalnym położeniem na wyspach wśród jezior i bagien. [...] A zatem wojowniczy Bolesław, rozpuściwszy zagony wszerz i wzdłuż po owym barbarzyńskim kraju, zgromadził niezmierne łupy, biorąc do niewoli mężów i kobiety, chłopców i dziewczęta, niewolników i niewolnice niezliczone, paląc budynki i wsie niezliczone; z tym wszystkim wrócił bez bitwy do Polski, choć właśnie bitwy ponad wszystko pragnął"68. Opisując konflikty Piastów z Prusami i wyprawy Krzywoustego przeciwko plemionom Sasinów i Galindów, K. Wiliński - w ślad za informacjami źródłowymi Rocznika Świętokrzyskiego dawnego i Kroniki książąt polskich - wskazał na to, że skutkiem tych najazdów było nie tylko czasowe uspokojenie sytuacji na pograniczu, ale przede wszystkim bardzo duże jego wyludnienie. Ludność pruska bowiem została uprowadzona do niewoli lub sama przeniosła się w inne, mniej dostępne rejony, a owa depopulacja wywołana przez wyprawy piastowskie była widoczna jeszcze w XIII w. ${ }^{69}$

Pozornie zimowa pora nie sprzyjała działaniom jazdy na szeroką skalę, z uwagi na zalegający śnieg i brak odpowiedniej ilości paszy dla koni (najprawdopodobniej zabierano ją ze sobą w postaci worków ziarna na wozach, lub w przypadku krótkich wypadów w sakwach troczonych do siodeł). Zaletą była jednak możliwość przepraw przez istniejące $\mathrm{w}$ innych okresach przeszkody wodne, które czasem z uwagi na głębokość czy szerokość nurtu bardzo je utrudniały bądź uniemożliwiały. Natomiast mroźna zima i odpowiednio gruby lód pozwalały na przejście w dowolnym miejscu, bez nadkładania drogi i szukania brodów. Zalety prowadzenia wojen w czasie zimy doceniali wieki wcześniej m.in. autorzy bizantyńscy ${ }^{70}$.

${ }^{68}$ Gall, L. III, cap. 24.

${ }^{69}$ K. WILIŃsKI, op. cit., s. 138-139.

${ }^{70}$ Różne sposoby walki przeciwko Słowianom najeżdżającym bałkańskie obszary Cesarstwa Wschodniorzymskiego opisywał w końcu VI w. PSEUdo MAURYCY: „Wyprawy na nich lepiej jednak 
Podczas wojen Bolesława Chrobrego z Cesarstwem siły piastowskie urządziły pierwszą z wypraw na teren Milska i na Budziszyn (1004) w porze zimowej. Jak pisał Thietmar: „Z tego powodu król [Bolesław] nawiązując do poprzedniej wyprawy wtargnął do kraju Milczan i gdyby nie przeszkodził mu duży opad śniegu, który zaraz stopniał, cała kraina uległaby wyludnieniu"71.

Bardzo dobrym przykładem wyprawy podjętej w zimie, umożliwiającej pełne zaskoczenie przeciwnika, było jeszcze jedno wydarzenie, które dowodziło nie tylko wyobraźni i śmiałości przedsięwzięcia, ale i skłonności do ryzyka. W 1068/1069 r. biskup Burchard z Halberstadtu nagłym wypadem doborowego oddziału jezdnych zdobył główny gród plemienia połabskiego Redarów - Retrę i bogate łupy oraz zniszczył tamtejszą sławną na całą Słowiańszczyznę świątynię Swarożyca. Po tej wojennej ekspedycji Sasów wspomniany gród już nie podniósł się z upadku. Zimowa wyprawa w trudnych warunkach pogodowych i szybkie pokonanie drogi, efekt zaskoczenia przyniosły nie tylko spektakularne powodzenie, ale i odpowiedni efekt psychologiczny, ponieważ Burchard zdobył tam świętego konia wspomnianego boga ${ }^{72}$.

\section{Rzeki i środowisko wodne w opisach Thietmara i Galla oraz ich rola w działaniach wojennych XI-XII wieku}

W obu kronikach znalazły się fragmenty opisujące sytuacje, gdy różne rzeki (niektóre nieznane z nazwy) odegrały istotną rolę podczas prowadzonych działań. Bardzo ważnym elementem w tym względzie było dokładne rozpoznanie możliwości przeprawy. Tak było w 1003 r. podczas wojny Henryka II z Bolesławem Chrobrym, gdy jego oddziały dokonały najazdu na kraj Głomaczów

\footnotetext{
urządzać zimą, kiedy drzewa obnażone z liści nie dają im osłony, a nadto śnieg zdradza ślady uciekających, a ich zasoby są szczupłe, jako ludzi nie zaopatrzonych, niezależnie od tego, że przy mrozie także i rzeki łatwo przechodzić”. Cf. G. LABUDA, Stowiańszczyzna starożytna i wczesnośredniowieczna. Antologia tekstów źródtowych, Poznań 1999, s. 77.

${ }^{71}$ Thietmar, L. VI; A.F. Grabski, Polska sztuka..., s. 114.

${ }^{72} \mathrm{Na}$ temat tej wyprawy $c f$. m.in. W.H. FrITZE, Beobachtungen zu Entstehung Wesen des Lutizienbundes, „Jahrbuch für Geschichte Mittel- und Ostdeutschlands” 1958, Bd. 7, s. 25; Historia Pomorza, red. G. Labuda, Poznań 1969, t. 1, cz. 1, s. 322-323; A. Turasiewicz, Dzieje polityczne Obodrzyców od IX wieku do utraty niepodlegtości w latach 1160-1164, Kraków 2004; A. Mich A£EK, Stowianie Zachodni. Jak ksztaltowaty się państwa narodowe?, Warszawa 2013, s. 71-73; J. STRZELCZyK, Stowianie potabscy, Poznań 2013, s. 74 i ostatnio P. BABIJ, op. cit., s. 157.
} 
i dostały się w pobliże grodu Strzała. Zanim siły polskie dokonały przejścia przez nurt Łaby, w skryty sposób starały się znaleźć brody na rzece, co jest wiadome z opisu Thietmara ${ }^{73}$. Czasem rzeki w sposób naturalny rozdzielały wrogie armie. Taka sytuacja została opisana w jego kronice w 1005 r., gdy w okolicach Krosna Odrzańskiego doszło do bitwy. Kronikarz informuje, że do udanej koncentracji armii cesarskiej doszło „nad krętą rzeką, zwaną po słowiańsku Bóbr, a po łacinie Castor. Bolesław jednak obwarowawszy brzeg tej rzeki i usadowiwszy się z wielkim wojskiem w Krośnie, przeszkadzał jak mógł w przeprawieniu się ich na drugą stronę ${ }^{74}$. Tylko znalezienie dogodnego brodu niespodziewanie zmieniło dalszy los wyprawy Henryka przeciw Polsce, o czym niżej.

Wydarzeniem związanym z dużą rzeką jaką jest Bug, odgrywający rolę granicy naturalnej między państwem Piastów a Rusią, które zostało w kronice Thietmara opisane stosunkowo obszernie, była krwawa bitwa stoczona pomiędzy wojskami Bolesława Chrobrego a armią Jarosława Mądrego. Biskup saski nazwał ją „żałosną klęską jaka wydarzyła się na Rusi”75. Dziejopis podał wprawdzie datę dzienną 22 lipca 1018 r., lecz do samego wydarzenia doszło „nad pewną rzeką”, gdzie Bolesław rozbił swój obóz, na drugim zaś brzegu znalazły się wojska ruskie. Przebieg tego starcia już w pierwszej fazie postawił armię księcia Jarosława w niekorzystnej sytuacji. Jak pisał Thietmar: „Tymczasem Polacy, wyzywając nieprzyjaciela, skłonili go do walki i z niespodziewanym szczęściem odepchnęli go od rzeki, którą obsadził. Zgiełk walki podniecił Bolesława. Zachęciwszy swoich towarzyszy do gotowości do walki i pośpiechu, przeprawił się szybko, choć z wielkim trudem przez rzekę. Wojsko nieprzyjacielskie, ustawione naprzeciw w zwartym szyku, nadaremnie usiłowało bronić swej ojczyzny. Albowiem ustąpiło już przy pierwszym starciu i nie stawiało potem silniejszego oporu. Poległa tam bardzo duża ilość uciekających, mała zaś wśród zwycięzców. Zginął po naszej stronie znakomity rycerz Eryk, którego cesarz trzymał przez długi czas w więzieniu. Od tej chwili Bolesław ścigał z wymarzonym wprost powodzeniem znajdujących się w rozsypce nieprzyjaciól, a mieszkańcy przyjmowali go wszędzie z darami i honorami"76.

73 Thietmar, L. V; A. NADOLSKI, op.cit, s. 101.

${ }^{74}$ Thietmar, L. VI. O walkach w okolicach Krosna Odrzańskiego w 1005 r. i w latach kolejnych ostatnio obszernie M. SAMP, op. cit., s. 38-50 (tam też inna literatura). Samo zaś miejsce przeprawy w 1005 r. lokalizuje on z dala od wspomnianego miasta, w rejonie Połęcka-Maszewa, Ibidem, s. 66.

75 Thietmar, L. VIII.

${ }^{76}$ Ibidem. 
O tym samym starciu pisał potem Gall, najprawdopodobniej nieco ubarwiając je i wzbogacając o te realia wojny, które zapewne sam poznał $\mathrm{z}$ autopsji towarzysząc różnym wyprawom Krzywoustego. Tak jak u Thietmara, owa rzeka, określona już wprost jako „Bug”, była tym miejscem, które w sposób naturalny przegrodziło obydwie armie, które niespodziewanie stanęły na swej drodze, ponieważ „w tym samym czasie król Bolesław najechał Ruś, a król Rusinów Polskę, jeden nie wiedząc o drugim"77. O ile na samym początku nie doszło do jakiegokolwiek starcia, poza obrzucaniem się przez obu władców obelgami, o tyle potem miało dojść do niego w sposób dość przypadkowy. Z opisu kronikarza (o którym nie wiadomo, czy rzeczywiście opisywał autentyczne fakty) wynikało, że Chrobry planował stoczyć bitwę „trzeciego dnia” z uwagi na jakieś święto, ograniczając się tylko do wysłania poselstwa do Jarosława ${ }^{78}$.

Czynnikiem, który miał doprowadzić do niespodziewanego starcia, było zachowanie czeladzi tak polskiej, jak i ruskiej, która wzajemnie prowokowała się rzucanymi obelgami. Początkowo polscy pachołkowie i kucharze mieli zajmować się tylko przygotowywaniem mięsa na posiłek, tj. jego płukaniem w nurtach rzeki i wyrzucaniem wnętrzności. Jednak rzucanie "grud i odpadków” oraz obelg przez Rusinów miało na celu sprowokowanie przeciwnika i z opisu wynika, że bardzo rozzłościło polską czeladź ${ }^{79}$. Momentem, który spowodował zerwanie wszelkich hamulców i żywiołowe przeprawienie się przez nurt rzeki przez rozgniewanych Polaków były strzały wypuszczane z drugiej strony rzeki, które - w domyśle - raniły lub zabijały. Do bitwy miało dojść niespodziewanie w porze południowej, gdy rycerstwo polskie spało, a broń (najprawdopodobniej włócznie i oszczepy oraz tarcze) zapewne były umieszczone ówczesnym zwyczajem przed namiotami. Rozwścieczona polska służba, kucharze i inni mieli zatem po przeprawie na drugi brzeg żywiołowo uderzyć na pachołków ruskich. Odgłosy walki miały obudzić samego Bolesława Chrobrego i innych rycerzy, którzy szybko dołączyli do walczącej służby. Rosnąca liczba ludzi, która miała przeprawiać się przez rzekę, w opisie kronikarza stworzyła wrażenie, że: „To nie woda, lecz jakaś zupełnie sucha droga”.

\footnotetext{
77 Gall, L. I, cap. 10.

${ }^{78}$ Ibidem.

79 Ibidem.

${ }^{80}$ Ibidem.
} 
Bardzo ciekawa analiza źródłowa bitwy nad Bugiem znalazła się w biografii Bolesława Chrobrego pióra Jerzego Strzelczyka. Wskazał on m.in., że pod tym względem zachodzi dość korzystna sytuacja, ponieważ owo wydarzenie zostało opisane w trzech różnych przekazach, zupełnie od siebie niezależnych. Bitwa ta widnieje bowiem we współczesnej owemu wydarzeniu kronice Thietmara oraz dwóch innych, późniejszych, tj. Powieści minionych lat Nestora (tradycja ruska) i kronice Galla Anonima (tradycja polska). Ten czynnik, bardzo sprzyjający historykom, ma to do siebie, że „wydarzenia 1018 r. są przedstawione w ten sposób, iż zasadniczy ich zrąb jest jednakowy, ale występują zasadnicze różnice w tendencji (wszak reprezentują różne strony konfliktu) - lecz także - czemu trudno się dziwić - niekiedy dość istotne różnice jeśli chodzi o same fakty" ${ }^{\text {"1 }}$.

Omawiając przekazy Thietmara i Nestora J. Strzelczyk wskazał na niemiecki punkt widzenia i polityczną rolę Cesarstwa w wyprawie 1018 r., natomiast przekaz Nestora miał uwidocznić bezpośrednią przyczynę, która podobno skłoniła Chrobrego i jego wojsko do przekroczenia nurtu Bugu (obelgi rzucane pod jego adresem przez wojewodę ruskiego imieniem Budy [Błud]. Jednak najbardziej interesujący dla poznania przyczyn owego starcia obu armii nad rzeką przekaz został zawarty u Galla. Dość mało wiarygodna jest informacja o zaskoczeniu Jarosława Mądrego, który miał łowić ryby na rzece gdzieś koło Kijowa, gdy usłyszał o bliskości armii Chrobrego. Dla kronikarza łowienie ryb było zajęciem zupełnie niegodnym władcy i „nierycerskim”, stąd też „sam Bog miał wydać to miasto [w domyśle Kijów - przyp. aut.], królestwo Rusinów i bogactwa! To rzekł i nie tracąc słów więcej rzucił się do ucieczki”. J. Strzelczyk słusznie zauważył, że: „Gallowi najwyraźniej pomyliła się chronologia wyprawy sprzed 100 lat, gdyż dopiero w drodze powrotnej z Kijowa kazał wojskom polskim wraz z ich stepowymi sprzymierzeńcami rozegrać bitwę nad Bugiem”. Ponadto wskazał, że przekaz kronikarza o obecności Połowców u boku wojsk polskich zawiera anachronizm, ponieważ „tych koczowników nie było wtedy jeszcze na Rusi”"2. U Galla jest za to bardzo ubarwiony literacko obraz boju nad Bugiem jako wyjątkowo krwawego starcia, gdzie miały zginąć nie tylko tysiące ludzi, lecz, że:

${ }^{81}$ J. Strzelczyk, Bolestaw..., s. 169. Podobną analizę przekazów źródłowych przeprowadził także w swej pracy A. Foryt, Wyprawa Chrobrego na Kijów 1018, Zabrze-Tarnowskie Góry 2018, s. 62-68. O bitwie nad Bugiem ostatnio także R. BARKowski, Kijów 1018, Warszawa 2019, s. 140 i nast.

82 J. STrzelczy K, Bolestaw..., s. 172. 
„tak wielki był tam rozlew krwi, iż nikt nie mógł przejść przez całą [tę] równinę jak tylko brodząc we krwi i [stąpając] po trupach, a cała rzeka Bug nabrała raczej barwy krwi niż wody rzecznej"\$3.

Jak widać z powyższego opisu, rzeka nie zawsze była skuteczną zaporą przeciw najazdowi. W działaniach wojennych dalszy ciąg marszu armii przez terytorium przeciwnika mógł niespodziewanie ulec korzystnej zmianie, gdy (np. zwiadowcom) udało się znaleźć jakiś bród lub miejsce stosunkowo płytkie, które umożliwiało przeprawę własnych wojsk. W tym względzie dobrym źródłem są przekazy Thietmara. Na przykład w roku 1003 wojska Bolesława przeszły dwukrotnie Łabę podczas najazdu na kraj Głomaczów (po uprzednim starannym rozpoznaniu brodów) i dotkliwie go spustoszyły ${ }^{84}$. Inny przypadek szczęśliwego odnalezienia brodu znalazł się w kronice wspomnianego biskupa merseburskiego, podczas przymusowego postoju armii Henryka II nad rzeką Bóbr w 1005 r., o czym wspomniano powyżej. Biskup pisał co następuje: „Kiedy król, zabawiwszy tam siedem dni, jął przygotowywać już okręty [czy raczej łodzie - przyp. aut. $]^{85}$ i mosty, Opatrzność Boża wskazała wysłanym przezeń wywiadowcom bardzo dogodny bród na rzece. $Z$ brzaskiem dnia, sześć legii udało się tam na rozkaz króla i bezpiecznie skorzystało z owego brodu. Straż Bolesława, która zauważyła to z daleka, zaniosła swemu władcy tę smutną i trudną do wiary wiadomośćc" ${ }^{6}$. Dla Chrobrego jak widać, niespodziewane przejście Bobru przez wojska najeźdźców stanowiło ogromne zaskoczenie, bo aż „trzykrotnie domagał się potwierdzenia tej wiadomości”. Natomiast dla Henryka II niespodziewane znalezienie niestrzeżonego brodu stanowiło bardzo korzystny zwrot $\mathrm{w}$ dalszym marszu w głąb ziem polskich. Tylko konieczność oczekiwania na nadejście sprzymierzonych z nim Luciców i szybkość odwrotu sił polskich uniemożliwiła szybkie rozstrzygnięcie wojny. Mimo to armia Henryka dotarła pod Poznań i rokowania z Bolesławem zapewniły, jak pisał Thietmar, ,na podstawie słusznych poprawek trwały pokój" $"$.

\footnotetext{
83 Gall, L. I, cap. 7.

84 Thietmar, L. V; A. NADolski, op. cit., s. 101.

${ }^{85}$ O wykorzystaniu łodzi jako środka przeprawy w działaniach 1004 i 1015 r. Thietmar, L. VII;
}

A. NADOLSKI, op. cit., s. 101.

86 Thietmar, L. VI.

87 Ibidem. 
Jeszcze bardziej korzystna dla armii inwazyjnej była sytuacja, gdy w jakimś miejscu nurt rzeki uległ widocznemu obniżeniu, a nie było to kompletnie znane miejscowym i w związku z tym nie pomyśleli oni, by go obsadzić wojskiem lub stworzyć jakiekolwiek przeszkody czy zapory. O takim fakcie wspominał Gall, gdy „w dzień św. Bartłomieja” (24 sierpnia) 1109 r. armia Henryka V niepodziewanie dla wszystkich przeprawiła się pod Głogowem „w takim miejscu, gdzie nikt tego nie oczekiwał, i gdzie nikt wcześniej się nie przeprawiał, ani nie wiedział o jego istnieniu i [dlatego] nikt go nie bronił; [przejścia dokonał] w zwartych szykach, z orężem w ręku, wobec nie przygotowanych mieszkańców" ${ }^{88}$. Zaskoczenie było tym pełniejsze, że jak informował kronikarz, mieszkańcy Głogowa byli na mszy z okazji dnia św. Bartłomieja w kościele (czy raczej w kościołach). To pozwoliło najeźdźcom na zagarnięcie sporych łupów i jeńców, a nawet dotarcie do namiotów ludzi, którzy pod wałami grodu je rozbili, chcąc go bronić. Według Galla, od zupełnej paniki miał uchronić obecny tam Bolesław Krzywousty, który „nie czmychnął jak bojaźliwy zając, lecz jak przystało na mężnego rycerza przemówił do swych ludzi i być może zapobiegł rozsypce sił" ${ }^{\prime}$.

Niekiedy rzeki były żywiołem bardzo groźnym. Thietmar opisywał kilka epizodów z czasów wojny z Bolesławem Chrobrym w latach 1015-1018. Podczas działań w 1015 r., syn Bolesława, Mieszko II wraz z „siedmioma legiami wojska” urządził wyprawę na Miśnię ${ }^{90}$. Gród był broniony przez niewielką liczebnie załogę dowodzoną przez grafa Hermana. Sytuacja była w pewnym momencie tak fatalna dla obrońców, że Herman modlił się już tylko do Chrystusa i św. Donata, a wałów grodowych musiały bronić kobiety. $\mathrm{Z}$ braku innych pocisków rzucały one w nacierających wojów Mieszkowych kamieniami, a pożary z braku wody gasiły... miodem. Hufce przybyłe z księciem Mieszkiem spustoszyły okolicę i paliły wszystko na swej drodze aż do Gany (Jahne). Również Miśnia była bliska upadkowi, a przed decydującym szturmem uratował obrońców nagły przybór wody w Łabie. Tylko to zmusiło siły piastowskie do odwrotu, bo gród miśnieński bronił się już ostatkiem sił¹'.

${ }^{88}$ Gall, L. III, cap. 5.

89 Ibidem. Na temat walk o wspomniany wyżej gród obszernie m.in. K. Olejnik, Gtogów 1109, Warszawa 1999, a ostatnio S. RosıK, op. cit., s. 115-120 i M. SAMP, Karol Maleczyński jako badacz wojny polsko-niemieckiej 1109 roku, „Colloquium Wydzialu Nauk Humanistycznych i Społecznych” 2018, nr 2, s. 13-125 (tamże bardzo obszerna analiza historiografii).

90 Thietmar, L. VII.

${ }^{91}$ Ibidem. 
Inne wydarzenie zapisane pod rokiem 1017 było związane ze sprzymierzonymi z wojskiem Henryka II pogańskimi Lucicami. Jeden z ich oddziałów musiał się przeprawić przez silnie wezbraną rzekę Muldę koło grodu Vurcin. Wody rzeki miały pochłonąć nie tylko 50 doborowych wojowników, ale Lucice stracili także wizerunek świętej bogini (najprawdopodobniej świętą stanicę) ${ }^{92}$. Kronikarz pisał dalej o tym, że wspomniane wydarzenie, jako „zła wróżba” było powodem, dla którego „źli ludzie [wśród Luciców] zaczęli namawiać innych do pozostania w domach i wystąpienia ze służby cesarza” i tylko "przywódcy odwiedli ich od tego na wspólnie odbytym zgromadzeniu"93.

Ten epizod znany z relacji Thietmara to według Pawła Babija wyraźne świadectwo, że ów pogański oddział był w istocie najprawdopodobniej „hufcem świątynnym, utrzymywanym ze skarbca nieznanej bogini”. Podobne oddziały w liczbie 50 zbrojnych mieli wówczas także biskupi z Hildesheim, Halberstadt, Münster, Osnabrück oraz Paderborn ${ }^{94}$.

Bywało, że w nurtach rzeki ginęło także rycerstwo. Takim przypadkiem był jeden z epizodów z wojny Bolesława II Szczodrego z Pomorzanami, którego opis znalazł się w kronice Galla. Ci ostatni mieli dokonać dalekiego najazdu w głąb ziem polskich. Chcąc jak najszybciej odeprzeć wrogą wyprawę, Bolesław miał nie czekać nawet na zebranie większych sił i dążył do tego, by jak najszybciej przeciąć drogę Pomorzanom. Do spotkania oddziałów piastowskich z najeźdźcami miało dojść nad jakąś niewymienioną z nazwy rzeką

Z opisu kronikarza wynika, że polskie rycerstwo, gdy dostrzegło "gromady pogan” na drugim brzegu, przypuściło gwałtowny na nie atak. Jeśli wierzyć relacji Galla, to rycerze chcieli jak najszybciej dosięgnąć wroga i w związku z tym, bez szukania jakiegokolwiek brodu, ani tym bardziej mostu, konno zaczęli się przeprawiać przez nurt rzeki. Jak pisał kronikarz: „I wielu pancernych poginęło tam przez własne zuchwalstwo, a pozostali zrzucili kolczugi i przepłynąwszy rzekę, odnieśli zwycięstwo, aczkolwiek okupione stratami. Od tego czasu odzwyczaiła się Polska od [noszenia] kolczug i dzięki temu każdy swobodniej

92 Ibidem.
93 Ibidem.
94 O wspomnianym wyżej przekazie Thietmara na temat tragedii 50-osobowego oddziału lucickiego, niosącego świętą stanicę w nurcie Muldy, cf. S. ZAKrZEWSKI, op. cit., s. 289-290 i ostatnio P. BABIJ, op. cit., s. 248-249 oraz M. SAMP, Krosno Odrzańskie..., s. 45-46.

95 Gall, L. I, cap. 25. 
nacierał na wroga i bezpieczniej przepływał stojącą na przeszkodzie rzekę bez ciężaru żelaza na sobie" ${ }^{96}$.

Powyższy opis był dla Galla przyczynkiem do tego, dlaczego od tej pory polscy pancerni mieli jakoby zarzucić obyczaj noszenia kolczug, „ulubiony w czasach Bolesława Wielkiego". Nad tym fragmentem, jak wskazał Andrzej Nadolski: „badacze dziejów wojskowości polskiej nie mogli przejść do porządku dziennego"97. Poparł on zresztą wiarygodność przekazu kronikarza kilkadziesiąt lat temu w jednej ze swych książek, motywując to właśnie warunkami naturalnymi pogranicza polsko-pomorskiego, gdzie zmagania zbrojne „toczyły się nad wielkim pasem bagien nadnoteckich lub w krajobrazie pojezierza, pełnym lasów, wód i moczarów [...] w krajobrazie tym ciężkie uzbrojenie mogło istotnie stanowić większą zawadę, niż pomoc" ${ }^{\text {"98 }}$. Ostatnio do tej kwestii odniósł się również J. Szymczak, który słusznie zauważył, że „Relacji tej nie można brać dosłownie, a jedynie jako wyraz przystosowania wojska polskiego do warunków pola walki na północy kraju"99. Epizod ten był uprzednio analizowany w dużej mierze w kontekście „moralizatorskim” u Galla, tj. odpowiedzialności króla

${ }^{96}$ Ibidem, L. II, cap. 6.

${ }^{97}$ A. NAdolski, Broń i strój rycerstwa polskiego w średniowieczu, Wrocław 1979, s. 58-60: „Ponieważ stał on w wyraźnej sprzeczności z utartym poglądem na ewolucję uzbrojenia ochronnego w średniowieczu. Powszechnie i wcale nie bezzasadnie przyjmuje się, że w miarę postępu czasu europejskie rycerstwo przykładało coraz to większą wagę do ochrony ciała, starało się okrywać zbrojami coraz szczelniejszymi, coraz pewniej zabezpieczającymi przed ciosem. Jakże pogodzić z tym relację Gallową? Najdalej szli ci, którzy po prostu negowali sens słów kronikarza, uważając je za wynik czystej fantazji. Inni dopatrywali się tu chęci upiększenia skromnej rzeczywistości, jaką Gall, przybysz z zagranicy miał zastać w swej nowej ojczyźnie. Dostrzegając, iż polskie rycerstwo jest uzbrojone gorzej od Niemców, czy też Czechów, autor kroniki stworzył legendę, mającą wykazać, iż rzekoma niższość była wynikiem świadomej rezygnacji, rozsądnego dostosowania się do szczególnych okoliczności. Na poparcie tego stanowiska można by przytoczyć inny fragment Gallowej kroniki, w którym jest mowa o tym, jak to walczącym z Polakami opancerzonym Czechom »kolczugi były ciężarem «".

98 Ibidem, s. 60: „W krajobrazie tym ciężkie uzbrojenie mogło istotnie stanowić większą zawadę, niż pomoc, a przecież zbroja nie była na stałe przyrośnięta do pleców rycerza! Historycy badający dzieje staropolskiej wojskowości w dobie jej największego rozkwitu doskonale wiedzą, jak często sławna husaria, będąca w zasadzie jazdą ciężkozbrojną, występowała do bitwy bez zbroi albo na piechotę, albo bez swych słynnych kopii”.

99 Badacz ten powołał się na analogiczną relację Kosmasa na temat wyprawy Henryka III na Czechy w 1040 r., gdy z powodu trudnych warunków terenowych, pancerni (loricati) musieli zejść z koni i pieszo iść przez drogę domažlicką, a sierpniowy upał i pragnienie zmusiły ich do zdjęcia zbroi i złożenia ich na tarcze (,super scuta suas loricas deiciunt). Cf. J. SzymCzAK, Rycerz w hetmie, zbroi i z tarcza, Warszawa-Bellerive-sur-Allier 2016, s. 90. 
za to co się stało i jego braku rozwagi (m.in. przez Jana Adamusa, Edwarda Skibińskiego i Przemysława Wiszewskiego, a w ostatnich latach Pawła Żmudzkiego i Norberta Delestowicza) ${ }^{100}$.

Rzeki i jeziora stawały się niekiedy naturalną przeszkodą, bardzo utrudniającą szybkie rozstrzygnięcie wyprawy wojennej czy kampanii. Relacja Galla opisująca kraj Prusów w kontekście wyprawy wojennej Krzywoustego na nich wskazywała na fakt, iż: „Ziemia zaś owa tak pełna jest jezior i bagien, że nawet zamkami i grodami nie mogłaby być tak ubezpieczona, toteż nie zdołał ich nikt dotąd podbić, ponieważ nikt nie mógł z wojskiem przeprawić się przez tyle bagien i jezior" ${ }^{101}$.

W odniesieniu do wspomnianej wyprawy Kazimierz Wiliński pisał co następuje: „Rozlane szeroko o tej porze roku rzeki, strumienie, poszerzone objętością wód bagna i moczary bardzo hamowały szybkość przemarszu wojsk polskich, a tym samym utrudniały czynnik zaskoczenia. W związku z tym Sasinowie zdążyli ukryć się w ostępach leśnych nie przyjmując jakiejkolwiek formy otwartego boju - o czym w źródłach jest absolutnie głucho - potrafili się uchronić przed poważniejszymi stratami"102. Roman Grodecki i Marian Plezia umieszczali wspomnianą wyprawę w pierwszych miesiącach 1108 r., „zaraz po wypędzeniu Zbigniewa”, również K. Wiliński sytuował ją na wiosnę tego roku ${ }^{103}$.

Podobna sytuacja została opisana u Galla Anonima, gdy podczas wojny z Czechami (1110) wody rzeki Cidliny zagrodziły siłom Krzywoustego drogę do łatwego, jak się wydawało zajęcia Pragi ${ }^{104}$. Wspomniana Cidlina była według kro-

100 J. Adamus, O monarchii Gallowej, Warszawa 1952, s. 25-26; E. SкIвIŃski, Biskup i monarcha, [w: Docendo discimus. Studia ofiarowane Profesorowi Zbigniewowi Wielgoszowi w siedemdziesiata rocznice urodzin, red. K. Kaczmarek, J. Nikodem, Poznań 2000, s. 102; P. Wiszewski, Domus Bolezlai. Wposzukiwaniu tradycji dynastycznej Piastów (do okoto 1138 r.), Wrocław 2008, s. 247-248; P. ŻMUdzki, Wtadca i wojownicy. Narracje o wodzach, druzynie i wojnach w najdawniejszej historii Polski i Rusi, Wrocław 2009, s. 316-317; N. Delestowicz, Bolestaw II Szczodry. Tragiczne losy wielkiego wojownika 1040/1042 - 2/4 IV 1091 albo 1082, Kraków 2016, s. 96-97. W przypadku P. Wiszewskiego i N. Delestowicza pojawia się także kontekst militarny, tj. zwyczaju noszenia pancerzy przez rycerstwo polskie i okoliczności jego zmian. Z kolei P. Żmudzki pisał o „pyrrusowym zwycięstwie” Bolesława nad Pomorzanami. N. Delestowicz stara się także powiązać wyprawę pomorską Bolesława II z wydaniem przywileju mogilneńskiego z 1065 r.

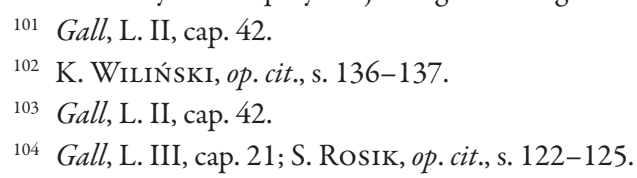


nikarza „pewną rzeką niewielką wprawdzie, lecz trudną do przebycia”. Bolesław kilkakrotnie chciał się wraz ze swymi siłami przeprawić przez jej nurt, lecz na drugim brzegu czekali już na niego Czesi wraz ze swym księciem ${ }^{105}$. Podczas tej samej wyprawy wojska Krzywoustego miały także okazję dotrzeć do górnej Łaby, która z uwagi na brak sił czeskich nie stanowiła poważnej przeszkody wodnej. To właśnie tam (jednak w bliżej nieznanym miejscu) młody książę i jego równie młodzi towarzysze według Galla chcieli podjęcia szybkiego marszu na Pragę, jednak ten śmiały zamiar miał zostać powstrzymany przez radę starszych, która zwróciła uwagę na szybko kończące się zapasy żywności ${ }^{106}$.

Jak już wcześniej wspomniano, nurt rzeki, nawet dość dużej, nie był w stanie uchronić mieszkańców kraju przed niszczącym najazdem. Przykładem w tej mierze jest wzmianka Galla Anonima o ataku Połowców, przybyłych ze stepów nadczarnomorskich na obszar Mazowsza, datowanym na rok 1100 lub 1101. Z opisu wynika, że nie był to pierwszy najazd tych dzikich koczowników, jaki dotknął ziemie polskie. Gall pisał, że: „czynili jak zwykle zagony, podzielili się na trzy lub cztery grupy i z dala od siebie przepłynęli nocną porą Wisłę. Z brzaskiem dnia następnego rozbiegli się pędem i zagarnąwszy niezliczone łupy, obciążeni zdobyczą, powrócili pod wieczór na drugi brzeg rzeki i tamże bezpieczni a zmęczeni rozbili namioty na nocny spoczynek"107. Sposób działania tych tureckich najeźdźców był typowy dla ludów koczowniczych i przypominał również późniejsze o wieki wyprawy czambułów tatarskich.

W kronice Galla Anonima znalazł się także krótki epizod, związany z akwenem wodnym, którego głównym motywem była wielka bitwa stoczona nad jeziorem. Dla ilustracji towarzyszących okropnościom wojny i sprawiedliwego rozstrzygnięcia burzliwego sporu między księciem Władysławem Hermanem a jego synem Zbigniewem, kronikarz wykorzystał opis krwawej bitwy z 1097 r., jaka rozegrała się nad wodami Gopła, nieopodal Kruszwicy. Był to swego rodzaju „sąd Boży”, bo jak pisał Gall: „Bóg wszechmogący tak wielkie okazał księciu Władysławowi miłosierdzie, że wytępił nieprzeliczone mnóstwo przeciwników, a z jego żołnierzy tylko niewielu śmierć zabrała”. Natomiast wody jeziora

105 Gall, L. III, cap. 21.

106 Gall, L. III, cap. 22.

107 Ibidem, L. II, cap. 20. O wspomnianym wyżej najeździe Połowców m.in. A.F. GraBskI, Polska wobec idei wypraw krzyżowych na przetomie XI i XII wieku, "Zapiski Historyczne” 1961, nr 26, z. 4, s. 48; K. MALECZyński, op. cit., s. 47-48; S. Rosik, op. cit., s. 79; D. WyBRANOwski, op. cit., s. 70. 
zabarwiły się krwią zabitych i rannych, a masa rozkładających się potem ciał spowodowała, że nikt nie chciał jeść pochodzących z niego ryb. To zaś z kolei według kronikarza miało wpływ na upadek znaczenia Kruszwicy, wcześniej słynącej z zasobności i bogactwa mieszkańców ${ }^{108}$.

Jednym z kluczowych momentów wojen z Pomorcami były walki o Nakło nad Notecią. Wspomniany gród należał do najbardziej istotnych pod względem ważności i obronności, jak pisał Gall - „na pograniczu Polski i Pomorza znajduje się mianowicie pewien gród, zwany Nakieł, niedostępny dzięki otaczających go bagnom i umocnieniom"109. Istotnym epizodem towarzyszącym podbojowi Pomorza były działania wojenne mające na celu zdobycie Nakła w 1109 r. Dla Bolesława Krzywoustego ta część kampanii była bardzo ważna, skoro zgromadził pod wałami nakielskimi całość swych wojsk, szacowanych przez A.F. Grabskiego na około 700 ludzi ${ }^{110}$.

Także i przez Pomorców ewentualne zdobycie Nakła było traktowane jako bardzo realne zagrożenie, które mogło znacznie pogorszyć ich położenie pod względem militarnym, a nawet zadecydować o dalszych losach tej wojny, skoro stosunkowo szybko zgromadzili co najmniej kilka tysięcy wojów. Dla oblężonych w Nakle pojawienie się tak licznej odsieczy było zapewne nadzieją na pokonanie Bolesława i uchronienie grodu oraz jego mieszkańców. Zatem bitwa miała się rozstrzygnąć nie w walkach o samo Nakło, lecz w jego pobliżu. Siły pomorskie dotarły pod gród, uprzednio pozbywszy się koni i chcąc tam się zjawić jak najszybciej, według Galla „przebijała się przez gąszcz leśny i schronienia dzikiego zwierza, nie trzymając się żadnych dróg i ścieżek. Mieli oni wynurzyć się na podobieństwo myszy polnych z nor" ${ }^{111}$. Tak nagłe pojawienie się dużej liczby wojów świadczy raczej o tym, że bardzo dobrze znali teren i sobie tylko znanymi szlakami leśnymi potrafili dotrzeć pod gród nakielski niezauważeni, przy pełnym zaskoczeniu przeciwnika. Opis Galla w tym fragmencie kroniki,

108 Ibidem, L. II, cap. 5: „Tyle bowiem rozlano tam krwi ludzkiej i taka masa trupów wpadła do sąsiadującego z grodem jeziora, że od tego czasu żaden dobry chrześcijanin nie chciał jeść ryby z owej wody. W ten sposób Kruszwica, opływająca wcześniej w bogactwa i [zasobna] w rycerstwo, zamieniła się nieomal w pustynię”. Na temat ówczesnych sporów dynastycznych i udziału w nich palatyna Sieciecha, m.in. M.K. BARAŃski, Historia Polski średniowiecznej, Poznań 2012, s. 92 i nast. i w ostatnich latach obszernie S. Rosık, op. cit., s. 61 i nast.; N. Delestowicz, Zbigniew..., s. 98-123 (tam też o samej bitwie kruszwickiej).

109 Gall, L. III, cap. 1.

110 A.F. Grabski, Polska sztuka..., s. 177.

111 Gall, L. III, cap. 1. 
to raczej zapis wrażeń kogoś zupełnie postronnego, kto po prostu nie mógł tak dobrze znać terenu jak miejscowi.

Kilka lat później znów doszło do bitwy o Nakło (w 1112/1113 r.) ${ }^{112}$. I tym razem silnie umocnionego grodu, położonego wśród bagien i rozlewisk Noteci nie dało się zdobyć ani przez zaskoczenie, ani z marszu. Bolesław potrzebował do tego zbudowania machin, z których wspomniane u dziejopisa są wieże oblężnicze ${ }^{113}$.

Pomorskie grody obronne, wsparte mniejszymi punktami oporu oraz warunkami naturalnymi, tj. siecią wodną, obszarami lasów i bagien dopełniały do początku XII w. obrazu systemu obronnego kraju. Jak pisali m.in. A.F. Grabski, K. Ślaski i Karol Olejnik, warunki naturalne i kształt terytorialny kraju nie ułatwiały zbytnio warunków skutecznej defensywy. Jedyną większą przeszkodą naturalną na pograniczu z Polską był pas wzgórz morenowych i bagniste obszary dolin Noteci i Warty ${ }^{114}$. Szczególnie newralgicznym obszarem było ujście Odry, Dziwny i Świny bronione przez sieć silnych grodów, takich jak Uznam, Lubin, Przytor, Kamień czy Szczecin, będące dla późniejszych najazdów duńskich po 1157 r. istotnym celem ${ }^{115}$. Zapewne podobnie jak w innych krajach, na wypadek najazdu rąbano przesieki w lasach i obsadzano zbrojnymi brody oraz przeprawy na rzekach ${ }^{116}$.

Warunki naturalne odegrały pewną rolę także w końcowej fazie wojen Bolesława Krzywoustego z Pomorcami, w latach 1119-1121/1122. W miesiącach wiosennych i letnich zdobycie Szczecina, tak bardzo ważnego dla Pomorzan grodu, utrudniały same warunki naturalne, tj. jeziora Dąbie, Miedwie, szerokie rozlewiska Odry Zachodniej czy obszary Puszczy Bukowej i Goleniowskiej, nie mówiąc już o samym bardzo dogodnym położeniu grodu szczecińskiego i jego obwarowaniach. Wojska Bolesława dotarły do niego nagłym wypadem, wykorzystując porę zimową i zamarznięte rozlewiska Odry ${ }^{117}$. Wydaje się, że

112 Ibidem.

113 Ibidem.

114 K. ŚLASKI, Granica wielkopolsko-pomorska w okresie wczesnego feudalizmu, „Przegląd Zachodni" 1954, nr 1/2, s. 102-106; A.F. Grabski, Polska sztuka..., s. 166; K. Olejnik, System obronny Pomorza do potowy XVII wieku, [w:] Z dziejów wojennych Pomorza Zachodniego 972-1945, red. B. Miśkiewicz, Poznań 1972, s. 50.

115 K. OlejNiK, System obronny..., s. 57-58.

116 Na temat wykorzystywania terenów leśnych do celów militarnych, w tym sporządzania przesiek i innych zapór, $c f$. S. SMOLKA, op. cit., s. 18-19; A. NADOLSKI, op. cit., s. 95.

117 S. Rosik, op. cit., s. 183-187. Szeroko o przebiegu misji chrystianizacyjnej w tym ostatnim grodzie nadodrzańskim, IDEM: Conversio Pomeranorum. Studium świadectwa o wydarzeniu 
owa strategia Bolesława Krzywoustego była raczej efektem, czy dostosowaniem się do, niewielkich stosunkowo możliwości militarnych ówczesnej Polski na bardzo trudnym do działań wojennych terenie. I tak, jak na działanie stosunkowo niewielkimi siłami, nie przekraczającymi chyba jednorazowo zbyt mocno pułapu tysiąca ludzi przy kolejnych wyprawach, księciu udało się to, co dla jego poprzedników okazało się zbyt trudne.

Jeśli chodzi o liczbę informacji na temat warunków naturalnych u Thietmara i Galla, w tym roli rzek w działaniach wojennych, wypraw na terenach leśnych, w górach czy czynnika przestrzeni, to w częstotliwości przekazów istnieje wyraźna asymetria. W kronice biskupa merseburskiego jedynie niektóre rzeki (Odra, Bóbr, Łaba, Mulda) pojawiają się w opisach wojen z lat 1002-1018 toczonych za panowania Bolesława Chrobrego. Dla Thietmara owe rzeki były zazwyczaj żywiołem bardzo groźnym (przykładem utonięcie 50 Luciców w Muldzie), czy nawet mającym wpływ na przerwanie działań wojennych (nagły przybór Łaby był powodem zaniechania oblężenia Miśni). Znaczącym opisem jest także problem forsowania Bobru w działaniach $1005 \mathrm{r}$. U Thietmara jako pierwszego znalazła się także informacja o bitwie stoczonej między Chrobrym a księciem Jarosławem nad Bugiem. W dość niewielkim stopniu zostały opisane działania w terenie leśnym - klęska armii Henryka II podczas bitwy w kraju Dziadoszan z 1015 r.

Natomiast w Kronice polskiej Galla Anonima spektrum czynników natury jest bez porównania większe. Puszcze i lasy, rzeki, jeziora i pasma górskie (Sudety) stanowią bardzo istotną część opisów działań władców piastowskich. Przypadki kampanii prowadzonych przeciwko Pomorzanom i Prusom podczas zimy są kolejnym elementem wzbogacającym opis wojen Bolesława Krzywoustego. Działania w górach i górskich lasach podczas wojen z Czechami i Morawianami (1103-1110) to dla Galla ogromne wyzwanie i powód do obaw. Zarazem jednak przesłanka do ukazania w korzystnym świetle ulubionego i podziwianego księcia Bolesława Krzywoustego, który potrafi sobie radzić nie tylko z wrogami na polu walki, ale i z naturą. Jednym z ciekawszych epizodów, związanym z wojnami Bolesława II Śmiałego z Pomorzanami, stanowiącym zarazem inspirację do budującej przypowieści, jest sprawa utonięcia grupy rycerzy

(XII wiek), Wrocław 2010, s. 324-329. Ostatnio na temat zdobycia Szczecina przez Krzywoustego: K. GuzIKowski, Najazdy zbrojne na Szczecin w XII wieku. Przyczyny - przebieg - skutki, [w:] Wojna - Wojsko - Bezpieczeństwo poprzez stulecia i epoki, red. A. Aкsamitowski, R. Ga£aj-Dempniak, H. WALCZaK, A. WojTASZaK, Szczecin 2016, s. 91-100. 
obciążonych kolczugami w jednej z rzek. Kolejną egzemplifikacją (jedną z wielu) jest opis działań wojennych Krzywoustego podczas wyprawy wojennej Henryka V w 1109 r., kiedy na niekorzyść najeźdźców książę z powodzeniem zastosował taktykę „wojny szarpanej” w terenie leśnym. W przypadku Galla wzbogacenie narracji towarzyszącej opisom działań wojennych Piastów o dodanie szerszego kontekstu warunków naturalnych jest nie tylko ważnym zabiegiem literackim, ale też w niektórych przypadkach cennym źródłem (często jedynym) do lepszego poznania przebiegu wojen XI-XII w.

\section{BIBLIOGRAFIA}

\section{Źrodła drukowane}

Anonim tzw. Gall, Kronika polska, tłum. i oprac. R. Grodecki, M. Plezia, Wrocław 1989.

Einhard, Vita Caroli, oprac. A. Gieysztor, Wrocław 1959.

Herbordi Dialogus de Vita S. Ottonis episcopi Babenbergensis, [w:] Monumenta Poloniae Historica, t. 7, Warszawa 1974.

Kronika Thietmara, tłum. M.Z. Jedlicki, Kraków 2002.

\section{Opracowania}

Adamus J., O monarchii Gallowej, Warszawa 1952.

Babij P., Wojskowość Stowian Potabskich, t. 1, Wrocław 2017.

Bachrach D.S., Niemiecka sztuka wojenna w czasach Mieszka I, Oświęcim 2016.

Banaszkiewicz J., Potrójne zwycięstwo Mazowszan nad Pomorzanami - Gall, II-49 - czyli historyk między „rzeczywistością prawdziwa”, a schematem porządkującym, [w:] Kultura średniowieczna i staropolska. Studia ofiarowane Aleksandrowi Gieysztorowi w 50-lecie pracy naukowej, red. D. Gawinowa et al., Warszawa 1991.

Barański M.K., Historia Polski średniowiecznej, Poznań 2012.

Bardach J., Historia państwa i prawa Polski, Warszawa 1964, t. 1.

Barkowski R., Budziszyn 1002-1018, Warszawa 2018.

Barkowski R., Kijów 1018, Warszawa 2019.

Bogacki M., Broń wojsk polskich w okresie średniowiecza, Zakrzewo 2009.

Cztowiek i przyroda w średniowieczu i we wczesnym okresie nowożytnym, red. W. Iwańczak, J. Bracha, Warszawa 2000. 
Delbrück H., Średniowieczna sztuka wojenna, t. 1: Wczesne średniowiecze, Oświęcim 2018.

Delestowicz N., Bolestaw II Szczodry. Tragiczne losy wielkiego wojownika 1040/1042 - 2/3 IV 1081 albo 1082, Kraków 2016.

Delestowicz N., Zbigniew. Książe Polski, Poznań 2017.

Dowiat J., Pochodzenie dynastii zachodnio-pomorskiej i uksztattowanie się terytorium księstwa zachodnio-pomorskiego, „Przegląd Historyczny” 1954, nr 45, z. 2-3.

Foryt A., Wyprawa Chrobrego na Kijów 1018, Tarnowskie Góry 2018.

Grabski A.F., Polska sztuka wojenna w okresie wozesnofeudalnym, Oświęcim 2015.

Grabski A.F., Polska wobec idei wypraw krzyżowych na przetomie XI i XII wieku, „Duch krzyżowy” Anonima Galla, „Zapiski Historyczne” 1961, t. 26, z. 4.

Grudziński T., Bolestaw Śmiaty, Warszawa 1983.

Guzikowski K., Najazdy zbrojne na Szczecin w XII wieku. Przyczyny - przebieg - skutki, [w:] Wojna - Wojsko - Bezpieczeństwo poprzez stulecia i epoki, red. A. Aksamitowski, R. Gałaj-Dempniak, H. Walczak, A. Wojtaszak, Szczecin 2016.

Halsall G., Wojna i spoteczeństwo w barbarzyńskiej Europie, Oświęcim 2015.

Hertel J., Pomorze w myśli politycznej elity intelektualnej wczesnośredniowiecznej Polski (Gall Anonim i Wincenty Kadtubek), „Zapiski Historyczne” 1982, t. 47, z. 4.

Kiersnowscy T. i R., Życie codzienne na Pomorzu wczesnośredniowiecznym. Wiek XII, Warszawa 1970.

Labuda G., Rozktad wspólnoty rodowej i ksztattowanie się stosunków wczesnofeudalnych (VI-XII wiek), [w:] Historia Pomorza, red. G. Labuda, t. 1, cz. 1, Poznań 1969.

Labuda G., Stowiańszczyzna starożytna i wczesnośredniowieczna. Antologia tekstów źródtowych, Poznań 1999.

Mackay C.S., Starożytny Rzym. Historia wojskowa i polityczna, Warszawa 2014.

Maleczyński K., Bolestaw III Krzywousty, Wrocław 1975.

Michałek A., Stowianie Zachodni.Jak ksztattowaty siępaństwa narodowe?, Warszawa 2013.

Miśkiewicz M., Studia z dziejów wojskowości, Warszawa-Poznań 1991.

Nadolski A., Broń i strój rycerstwa polskiego w średniowieczu, Wrocław 1979.

Nadolski A., Polskie sity zbrojne w czasach Bolestawa Chrobrego. Zarys strategii i taktyki, Oświęcim 2018.

Nicolle D., Jeździec Karolingów 768-987, Oświęcim 2018.

Nicolle D., Podbój Saksonii lata 782-786, Oświęcim 2017.

Olejnik K., Gtogów 1109, Warszawa 1999.

Olejnik K., System obronny Pomorza do potowy XVII wieku, [w:] Z dziejów wojennych Pomorza Zachodniego 972-1945, red. B. Miśkiewicz, Poznań 1972.

Oman C., Sztuka wojenna w'średniowieczu, t. 1, Oświęcim 2013.

Powierski J., Stosunkipolsko-pruskie do 1230 r. ze szczególnym uwzględnieniem roli Pomorza Gdańskiego, Toruń 1968. 
Riché P., Życie codzienne w państwie Karola Wielkiego, Warszawa 1979.

Rochala P., Las Teutoburski 9 n.e., Warszawa 2005.

Rosik S., Bolestaw Krzywousty, Wrocław 2013.

Rosik S., Conversio Pomeranorum. Studium świadectwa o wydarzeniu (XII wiek), Wroclaw 2010.

Rymar E., Rodowód książąt pomorskich, Szczecin 2005.

Samp M., Karol Maleczyński jako badacz dziejów wojny polsko-niemieckiej 1109 roku, „Colloquium Nauk Humanistycznych i Społecznych” 2018, nr 2.

Samp M., Krosno Odrzańskie 1005 i 1015, Zabrze-Tarnowskie Góry 2019.

Schünemann K., Deutsche Kriegsführung im Osten während Mittelalters, „Deutsches Archiv für Geschichte des Mittelalters”1938, Jg. 2.

Skibiński E., Biskup i monarcha, [w:] Docendo discimus. Studia ofiarowane Profesorowi Zbigniewowi Wielgoszowi $w$ siedemdziesiata rocznice urodzin, red. K. Kaczmarek, J. Nikodem, Poznań 2000.

Smolka S., Mieszko Stary i jego wiek, Warszawa 1959.

Sochacki J., Pomorska polityka Piastów w X-XI wieku, „Gdańskie Studia z Dziejów Średniowiecza” Pielgrzymi, pogrobowcy, prebendarze, red. B. Śliwiński, t. 15, Malbork 2009.

Spors J., Pochodzenie dynastii ksiażecych na Pomorzu Zachodnim w XI i XII w. - w szczególności Świętobora i Świętopetka z Kroniki Galla Anonima, „Roczniki Historyczne” 1983, t. 49.

Spors J., Studia nad wczesnośredniowiecznymi dziejami Pomorza Zachodniego XII - pierwsza potowa XIII wieku, Słupsk 1988.

Strzelczyk J., Bolestaw Chrobry, Poznań 1999.

Strzelczyk J., Stowianie potabscy, Poznań 2013.

Szymczak J., Rycerz i jego konie, Warszawa-Bellerive-sur-Allier 2018.

Szymczak J., Rycerz w hetmie, w zbroi i z tarcza, Warszawa-Bellerive-sur-Allier 2016.

Ślaski K., Granica wielkopolsko-pomorska w okresie wczesnego feudalizmu, „Przegląd Zachodni" 1954, nr 1/2.

Ślaski K., Zasięg lasów Pomorza w ostatnim tysiącleciu, „Przegląd Zachodni” 1951, z. 5/6.

Trawkowski S., Bolestaw III Krzywousty, [w:] Poczet królów i książąt polskich, red. A. Garlicki, Warszawa 1978.

Trawkowski S., Zbigniew, [w:] Poczet królów i książąt polskich, red. A. Garlicki, Warszawa 1978.

Turasiewicz A., Dzieje polityczne Obodrzyców od IX wieku do utraty niepodlegtości w latach 1160-1164, Kraków 2004.

Tyc T., Polska a Pomorze za Krzywoustego, „Roczniki Historyczne” 1926, t. 2.

Wiliński K., Walki polsko-pruskie w X-XIII wieku, „Acta Universitatis Lodziensis”, Folia Historica 15, 1984. 
Wiszewski P., Domus Bolezlai. W poszukiwaniu tradycji dynastycznej Piastów (do okoto 1138 r.), Wrocław 2008.

Wybranowski D., Jeszcze raz o taktyce wojen pomorskich Bolestawa Krzywoustego i okolicznościach ich finatu, „Przegląd Zachodniopomorski” 2017, t. 32, z. 2.

Wybranowski D., Organizacja wojskowa Księstwa Pomorskiego od XII do potowy XIII wieku, [w:] Pomorze militarne XII-XXI wiek, red. E. Rymar, K. Kozłowski, Szczecin 2004.

Zakrzewski S., Bolestaw Chrobry Wielki, Kraków 2000.

Żmudzki P., Wtadca i wojownicy. Narracje o wodzach, drużynie i wojnach w najdawniejszej historii Polski i Rusi, Wrocław 2009.

\section{Dariusz Wybranowski \\ NATURAL CONDITIONS AS AN ONE FACTOR BELONGING TO WAR CAMPAIGNS IN THIETMAR'S AND GALLUS ANONYMOUS'S NARRATION. APPENDIX TO FIRST PIAST'S POLICY}

Summary. Author's main scientific base for present publication of are such medieval sources: Chronicle of Bishop Thietmar of Merseburg and later, Polish Chronicle of Gallus Anonymous. The main questions of ananalysis were: are a or long distance (also transport, logistic problems and food for medieval armies), the war campaigns leading in the forests and in the mountains, also rivers and their place in medieval campaigns. For author is a an important question - level of presence all this elements of a natural enviromnents in both chronicles for description of campaigns and battles. - Are for these medieval writers forests, rivers, lakes, mountains is an integral parts of chronicle's battle narration or only an indirect information?

In this article, an author has trying to prove that in Gall Anonymous narration, the prince Boleslaw the Wrymouth is a great winner (not only as a militar leader) of fight with wild nature (crossing the Sudety Mountains with army during war campaigns against Czech's and Moravians, a very long way across the deep forests of Pomerania, and in the land of Prussians). For bishop Thietmar, an occasion to presenting the factor of wild natural environment are the wars against prince Boleslaw the Brave (1002-1018), and the great battle of Bug River (1018) with great prince Jaroslav the Wise from Kiev. For anannalist from Saxonia the main element of war descriptions in some cases are big rivers and as a danger. A good exampleis a description of the battle in deepforest, ended as a collapse of emperor Henry's the Second army in the land of Dziadoszanie tribe's (Silesia) in 1015. But for Thietmar, some informations concerned with natural conditions in his narration are only indirectin formation, not a main element.

The situation is quite different in Gall Anonymous's narration. Deep forests, rivers, high and dangerous mountains are integral part of relations about war campaigns of Polish kings and princes from Piast dynasty. A longride to Kołobrzeg (Pomerania) during "five days" (1103) is a good example for Gallus of prince's Boleslaw the Wrymouth victory against nature and a long distance. The war of prince Wrymouth's against Emperor Henry the Fifth (1109) and German army (as the invaders) is one exemplification more for "partisan fighting” in wild forest. 
One of the most interesant episode in Gallus Anonymous narration's is a campaign of Boleslaw the Second (Audacious) against the Pomeranians (date unknown). In the deep river many of his knights in armors were sunk. This relations was anexample as a morality play (too brave king and their knights) to punishment for a mad reckleness. A great bloody battle near Gopło Lake (1097) is an example of "God's judgement" and the punishment for in habitants of Kruszwica stronghold. The number of exemplifications concerned with natural conditions is quite greater in Gallus's Chronicle than in Thietmar's. These relations having not only meaning as a simply information. Some more elements of Anonymous's Chronicle are: classical erudition of an author and the great literary value.

Keywords: Thietmar of Merseburg, Gallus Anonymous, war in the Middle Ages, Rivers as an element of war campaigns, campaigns in wild forest and in the mountains, Wars during the first Piast's rules 